UNIVERSIDADE DE SÃO PAULO

FACULDADE DE FILOSOFIA, CIÊNCIAS E LETRAS DE RIBEIRÃO PRETO PROGRAMA DE PÓS-GRADUAÇÃO EM PSICOBIOLOGIA

RICARDO MARINHO DE MELLO DE PICOLI

\title{
Alterações dos Estados de Ânimo Presentes de jovens atletas de futebol em função do decurso temporal durante um período competitivo.
}

VERSÃO CORRIGIDA

Ribeirão Preto/SP 



\title{
Alterações dos Estados de Ânimo Presentes de jovens atletas de futebol em função do decurso temporal durante um período competitivo.
}

\author{
VERSÃO CORRIGIDA
}

Dissertação apresentada à Faculdade de Filosofia, Ciências e Letras de Ribeirão Preto - Universidade de São Paulo para obtenção do título de Mestre em Ciências.

Área de concentração: Psicobiologia.

Orientador: Prof. Dr. José Lino Oliveira Bueno

Ribeirão Preto/SP 
AUTORIZO A REPRODUÇÃO E DIVULGAÇÃO TOTAL OU PARCIAL DESTE

TRABALHO, POR QUALQUER MEIO CONVENCIONAL OU ELETRÔNICO, PARA

FINS DE ESTUDO E PESQUISA, DESDE QUE CITADA A FONTE.

Catalogação na publicação Serviço de Biblioteca e Documentação

Departamento de Psicologia

Universidade de São Paulo - Ribeirão Preto

Picoli, Ricardo Marinho de Mello de.

Alterações dos Estados de Ânimo Presentes de jovens atletas de futebol em função do decurso temporal durante um período competitivo/ Ricardo Marinho de Mello de Picoli; orientador: Prof. Dr. José Lino Oliveira Bueno Ribeirão Preto, 2016.

$75 \mathrm{p}$.

Dissertação de Mestrado apresentada à Faculdade de Filosofia, Ciências e Letras de Ribeirão Preto/Universidade de São Paulo - Departamento de Psicologia.

1. Estados de ânimo; 2. Futebol; 3. Decurso temporal; 4. Psicologia do Esporte; 
Nome: Picoli, Ricardo Marinho de Mello de

Título: Alterações dos Estados de Ânimo Presentes de jovens atletas de futebol em função do decurso temporal durante um período competitivo.

Dissertação apresentada à Faculdade de Filosofia,

Ciências e Letras de Ribeirão Preto - Universidade de

São Paulo para obtenção do título de Mestre em Ciências.

Aprovado em: 29 de fevereiro de 2016.

Banca Examinadora

Prof. Dr. José Lino Oliveira Bueno Instituição: FFCLRP-USP

Julgamento: APROVADO

Prof. Dr. José Aparecido da Silva

Instituição: FFCLRP-USP

Julgamento: APROVADO

Profa. Dra. Paula Teixeira Fernandes

Instituição: FEF/UNICAMP

Julgamento: APROVADO 

Dedico este trabalho a todos que me ajudaram direta ou indiretamente, especialmente à minha família e meus amigos. 



\section{AGRADECIMENTOS}

Aos meus pais, Thais e Vitor, e minha família pelo apoio de sempre, pelo carinho e pela torcida.

Ao Prof. Dr. José Lino Oliveira Bueno que abriu as portas do laboratório para que eu pudesse realizar esse estudo e pela oportunidade de conviver e aprender, aproveitando um pouco de sua experiência profissional e pessoal.

Ao João Luís Segala Borin, que faz o laboratório funcionar e segura a peteca de todo mundo.

A todos os companheiros de laboratório que sempre estiveram disponíveis e dispostos a discutir novas ideias, conversar e me aturar. Agradecimento especial aos companheiros Victor Cavallari Souza e Renan Cardoso da Silva pelas discussões, resenhas e auxílio na coleta e ao Estêvão Gonçalves Bittar pela grande ajuda na análise dos dados.

À querida Lívia Mariussi Segato que fez todos os trâmites institucionais no Botafogo FC de Ribeirão Preto para que essa pesquisa pudesse acontecer e pelo apoio fraternal.

À saudosa Bianca Marcelino de Souza (in memorian) e à Renata Lameira Oliveira que foram fundamentais para que eu desse o primeiro passo a essa realização.

A todos os meus amigos, em especial a Os Andarillos - André Nicolau, André Cortegoso Prezenszky, Gabriel Leal Bombarda e Lucas do Carmo Lima - pela força, pelas risadas e por manter meu equilíbrio mental nas horas mais difíceis.

À Coordenação de Aperfeiçoamento de Pessoal de Nível Superior - CAPES - pela concessão da bolsa de mestrado e conseguinte apoio financeiro para realização desse estudo.

À Ana Luiza Mendonça, Laísa Francielle Mariano Ramazzotto, João Soares da Cunha Neto e Mayra Antonelli Ponti pelo apoio e pela força na reta final desse ciclo. 



\section{RESUMO}

Picoli, R. M. M. (2016). Alterações dos Estados de Ânimo Presentes de jovens atletas de futebol em função do decurso temporal durante um período competitivo. Dissertação de Mestrado. Faculdade de Filosofia, Ciências e Letras de Ribeirão Preto. Universidade de São Paulo. Ribeirão Preto-SP.

São escassos os estudos que analisam o contínuo temporal dos estados de ânimo ao longo de um período competitivo esportivo. Embora os estados de ânimo pareçam estáveis ao longo do tempo, diferentes estímulos e contextos presentes modificam a intensidade e a valência desses estados. Além disso, há fenômenos psicológicos como decaimento, em que traços de informação perdem sua ativação devido, principalmente, à passagem do tempo e a expectativa, que é a espera pela ocorrência de um evento em um determinado tempo. $\mathrm{O}$ objetivo desse estudo foi examinar as alterações dos estados de ânimo em jovens atletas de futebol, separados por posição e função, que ocorreram num período competitivo, em função do decurso temporal. Assim, processos como decaimento dos estados de ânimo e a influência da expectativa pela ocorrência jogo foram analisados, bem como a influência do contexto nas variações dos estados de ânimo dos atletas. Participaram deste estudo 18 jovens atletas (média de 15,4 anos $\pm 0,266$ ) de um clube de futebol que estava disputando um campeonato estadual. Para o acesso aos estados de ânimo, foi utilizada a versão reduzida da Lista de Estados de Ânimo Presentes (LEAP), juntamente com um formulário de instruções de preenchimento, aplicada minutos antes de alguns treinamentos e jogos. Foram calculados os valores de presença de cada Fator da LEAP em cada evento para cada participante. Os dados foram coletados em três tipos de Eventos: antes do último treino antecedente ao jogo (Treino-Pré), antes do jogo (Pré-jogo) e antes do primeiro treino subsequente ao jogo (Treino-Pós). Os 18 jogadores foram divididos em dois grupos: Ações Defensivas (AD) e Ações Ofensivas (AO). Foram encontrados padrões de alteração dos estados de ânimo, representados pelos Fatores II (Fadiga), VII (Interesse) e XII (Serenidade) da LEAP, em função do decurso temporal, permitindo a análise dos processos de decaimento desses estados de ânimo e a influência da expectativa nessas alterações. Também foi encontrado que alguns estados de ânimo diferiram seus padrões de alteração de acordo com um intervalo temporal (Fatores IV Limerência/Empatia e; VII - Interesse), bem como tiveram valores de presença diferentes na comparação entre esses intervalos. Além disso, os Fatores III (Esperança), V (Fisiológico) e XI (Receptividade) apresentaram padrões de alteração em função do decurso temporal em diferentes intervalos temporais. Variáveis contextuais, como o resultado das partidas e a competição esportiva em si, também foram influentes nessas alterações. Fadiga, esperança, empatia, estados ligados à propriocepção, interesse, receptividade e serenidade foram os estados de ânimo presentes durante todo o estudo. Ressalta-se a importância de incluir a temporalidade como variável influente nos modelos de variação de processos neurobiológicos, sobretudo nas investigações acerca de aspectos subjetivos como os estados de ânimo.

Palavras-chave: estados de ânimo, futebol, decurso temporal, psicologia do esporte. 



\begin{abstract}
Picoli, R. M. M. (2016). Youth soccer players mood changes in function of time course during a competitive season. Dissertação de Mestrado. Faculdade de Filosofia, Ciências e Letras de Ribeirão Preto. Universidade de São Paulo. Ribeirão Preto-SP.
\end{abstract}

There are few studies analyzing the time course of mood during a competitive sport's season. Although moods seem stable over the time course, different stimuli and present contexts change their intensity and valence. Furthermore, there are psychological phenomena like the decay process, in which information traces lose activation with the passage of time and expectancy, which is a waiting for an occurrence of an event in a given time. Therefore, the aim of this study was to exam mood changes in youth soccer players, grouped by position and role, which occurred during a competitive season, in function of time course. Processes like mood decay and the influence of expectation for the game were analyzed, as well as the influence of context in the athletes' mood variations. Eighteen young players $(15.4 \pm 0,266$ year-old) from a soccer club, which was playing for a state championship, participated in this study. For the assessment of mood, a short form of Lista de Estados de Ânimo Presentes (LEAP - Present Mood List) was used, along with instructions to fill the form, applied few moments before some training sessions and matches. Presence values of each LEAP's Factor were calculated for each participant in each event. The data was collected in three types of events: prior to the last trainning session before the match (Treino-Pré), at a few moments before the match (Pré-jogo) and prior to the first training session after the match. The eighteen players were divided in two groups: Defensive Actions (AD) and Offensive Actions (AO). Results have shown patterns of mood changes, represented by LEAP's Factors II (Fatigue), VII (Interest) and XII (Serenity), in function of time course, allowing the analysis of mood decay process and the influence of the expectation in these changes. Also, some moods showed different patterns in function of a given time interval (Factors IV Limerence/Empathy and VII - Interest), as well as different presence values in these time intervals' comparison. Moreover, Factors III (Hope), V (Physiologic) and XI (Receptivity) have shown patterns of mood changes in function of time course in different intervals of time. Contextual variables, like the outcome of the matches and the sport competition itself, were influential in these changes. Fatigue, hope, empathy, states related to proprioception, interest, receptivity and serenity were the present moods all along the study. The importance of including temporality as an influential variable in neurobiological models is noteworthy, especially in the investigations about subjective aspects like mood.

Keywords: Mood, Soccer, Time Course, Sport Psychology. 



\section{LISTA DE TABELAS E FIGURAS}

Tabela 1. Representação das cargas de correlação de cada locução com o Fator (Tabela III, pp.142-43. Engelmann, 1986).

Tabela 2. Média dos valores de presença de cada Fator da LEAP divididos por grupo, evento e momento.

Figura 1. Representação do procedimento de ajuste das escalas e dos valores de presença dos Fatores.

Figura 2. Médias dos grupos no Fator I (Humilhação/Raiva) da LEAP em cada evento.

Figura 3. Médias dos grupos no Fator II (Fadiga) da LEAP em cada evento.

Figura 4. Médias dos grupos no Fator III (Esperança) da LEAP em cada evento.

Figura 5. Médias dos grupos no Fator IV (Limerência/Empatia) da LEAP em cada evento.

Figura 6. Médias dos grupos no Fator V (Fisiológico) da LEAP em cada evento.

Figura 7. Médias dos grupos no Fator VI (Repulsa) da LEAP em cada evento.

Figura 8. Médias dos grupos no Fator VII (Interesse) da LEAP em cada evento.

Figura 9. Médias dos grupos no Fator VIII (Surpresa) da LEAP em cada evento.

Figura 10. Médias dos grupos no Fator IX (Fome) da LEAP em cada evento.

Figura 11. Médias dos grupos no Fator X (Descaso/Inveja) da LEAP em cada evento.

Figura 12. Médias dos grupos no Fator XI (Receptividade) da LEAP em cada evento.

Figura 13. Médias dos grupos no Fator XII (Serenidade) da LEAP em cada evento.

Figura 14. Padrões de alteração dos Fatores da LEAP representativos durante o período estudado. 



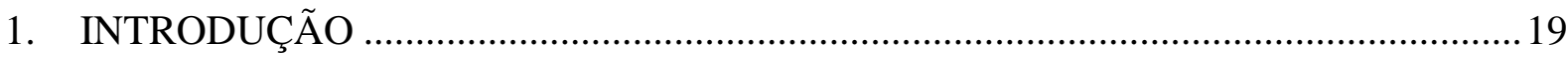

1.1 Psicologia do Esporte e Aspectos emocionais ............................................................. 19

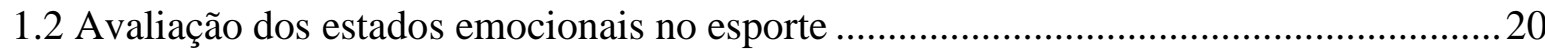

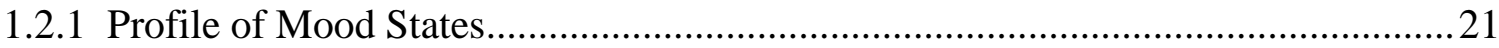

1.2.2 Lista de Estados de Ânimo Presentes (LEAP) ..................................................... 22

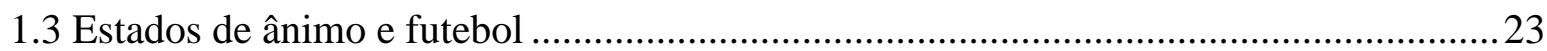

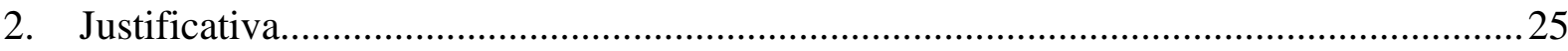

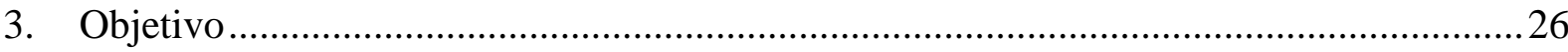

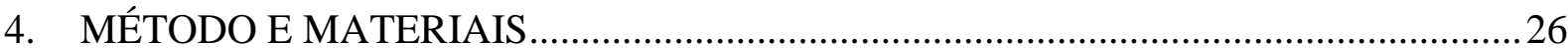

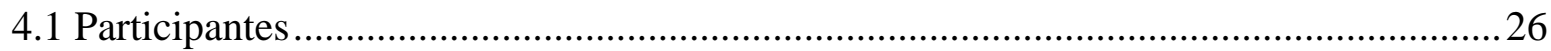

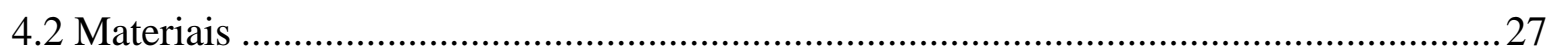

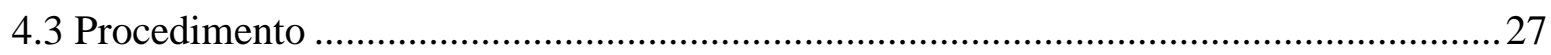

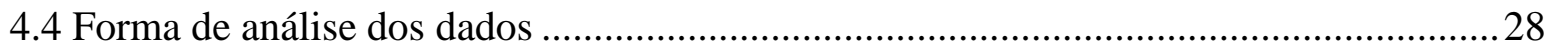

4.4.1 Cálculo das escalas e valores de presença dos Fatores da LEAP .............................30

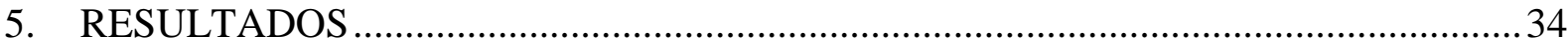

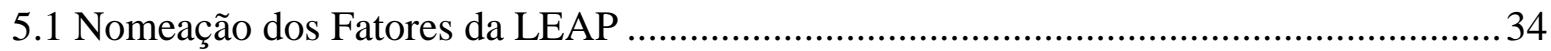

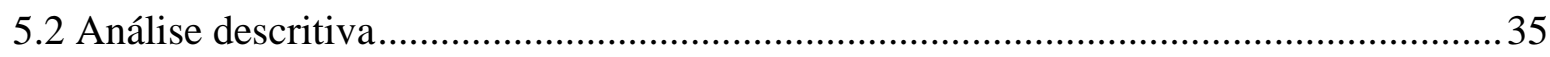

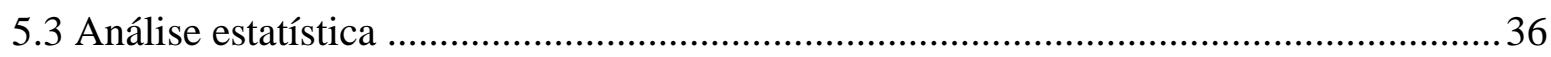

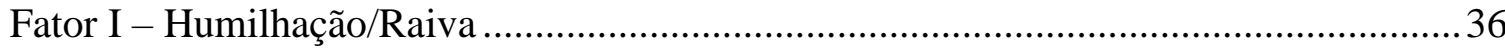

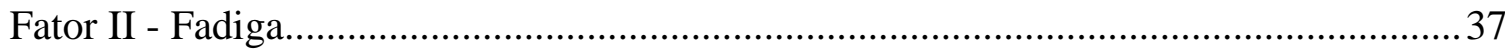

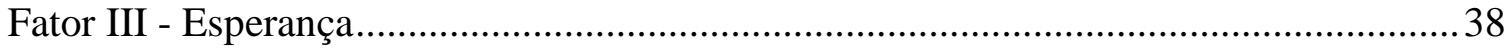

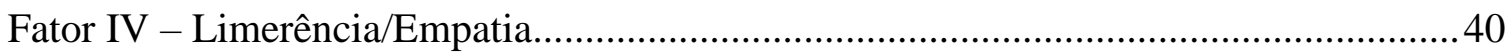

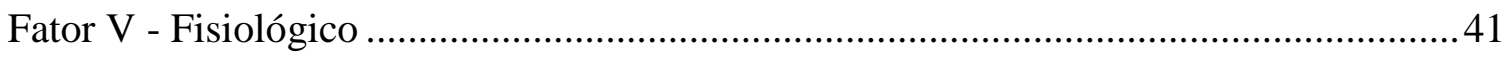

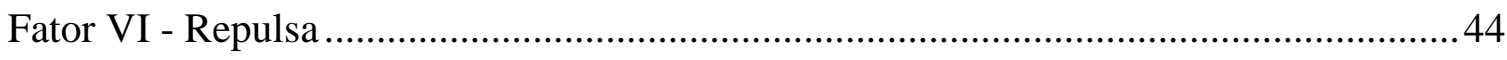

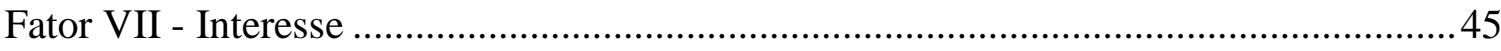

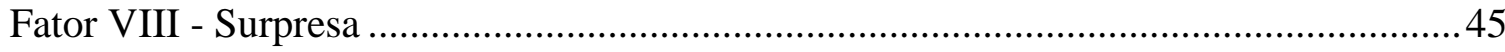

Fator IX - Fome

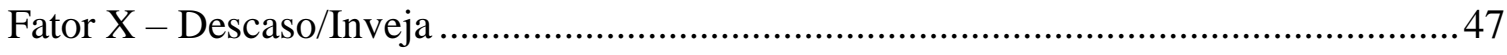

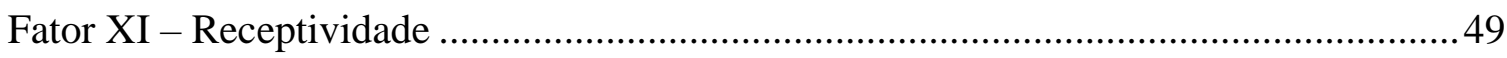

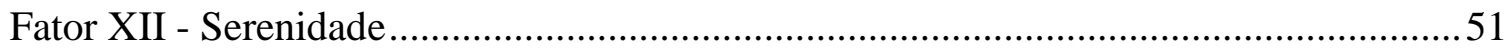

3.5 Análise das alterações dos estados de ânimo presentes em função do decurso temporal 
5.4 Análise das alterações dos estados de ânimo presentes em função do intervalo temporal

5.6 Análise das alterações dos estados de ânimo em função da interação entre decurso

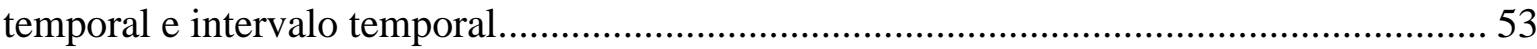

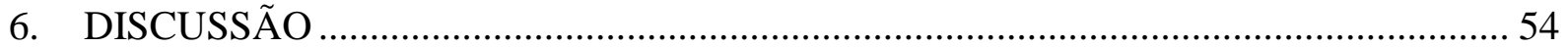

6.1 Alterações dos estados de ânimo presentes em função do decurso temporal .................58

6.2 Alterações dos estados de ânimo presentes em função do intervalo temporal............... 59

6.3 Alterações dos estados de ânimo presentes em função da interação entre decurso

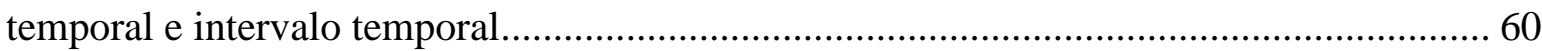

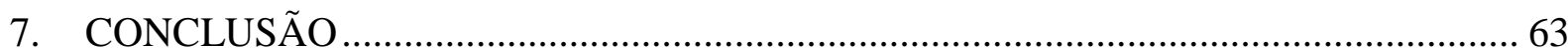

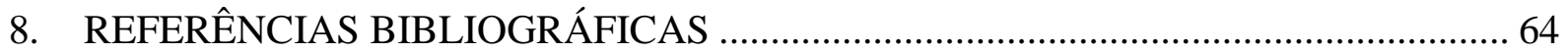

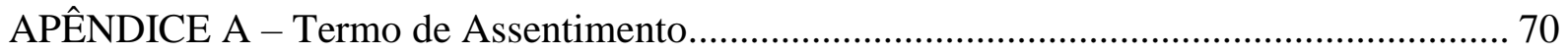

APÊNDICE B - Termo de Consentimento Livre e Esclarecido ............................................ 72

ANEXO A - Lista de Estados de Ânimo Presentes (Engelmann, 1986)................................. 74 


\section{INTRODUÇÃO}

\subsection{Psicologia do Esporte e Aspectos emocionais}

Devido ao grande interesse em avaliar como e quais aspectos psicológicos influenciam o rendimento dos atletas, bem como a influência do treinamento e da competição nos mesmos aspectos, o número de pesquisas em Psicologia do Esporte tem crescido nos últimos anos (Vieira, Nascimento Júnior, \& Vieira, 2013). Dentro desse campo de estudo, os aspectos emocionais têm despertado especial interesse, sobretudo a relação dessas emoções com o rendimento e com o bem-estar dos atletas.

As primeiras investigações sobre as emoções no contexto esportivo tiveram como enfoque o estudo da ansiedade, em detrimento a outros aspectos emocionais (Dias, CorteReal, Cruz, \& Fonseca, 2013). Segundo Dias et al. (2013) o estudo da ansiedade, num primeiro momento, concentrou-se na intensidade dos seus sintomas visando desenvolver técnicas e estratégias para que fosse diminuída, visto que era considerada prejudicial aos atletas, afetando negativamente seu desempenho. No entanto, a compreensão do papel da ansiedade no desempenho dos atletas mostrou-se insuficiente para explicar muitos dos processos e mecanismos de funcionamento psicológico (fatores cognitivos, motivacionais e emocionais).

$\mathrm{O}$ acesso aos estados emocionais em pesquisas no contexto esportivo foi feito de diversas formas, com os mais variados instrumentos e em diferentes modalidades. De la Vega Marcos et al. (2008) apontam que a avaliação de toda a esfera emocional tem sido realizada a partir de sistemas distintos: análises de observação, entrevistas, indicadores psicofisiológicos, escalas de autoavaliação, autorrelatos, análises das Zonas Ótimas de Rendimento Individual IZOF (Hanin, 1997) e o emprego de vários testes específicos como: Inventário de Ansiedade Traço-Estado - STAI (Spielberger, 1983); Inventário de Ansiedade Competitiva no Esporte CSAI-2 (Martens, Vealey, \& Burton, 1990); Inventário de Traço-Estado de Expressão da Ira 
- STAXI (Spielberger, 1989); Escala de Ansiedade Esportiva - SAS (Smith, Smoll, \& Schultz, 1990) e Profile of Mood States - POMS (McNair, Lorr, \& Droppelman, 1971; Morgan, 1980).

No entanto, a maioria dos instrumentos de avaliação emocional no esporte não foi elaborada no Brasil e os que foram se concentram na avaliação do estresse (De Rose Junior, 1998; Noce \& Samulski, 2002a, 2002b; Samulski, 1992). Bueno e Di Bonifácio (2009) apontam que, além de estudar aspectos emocionais específicos como ansiedade, estresse e raiva, é importante que se acompanhe as alterações num perfil emocional, indicados por estados emocionais mais representativos em situações esportivas.

É importante destacar que existe uma diferença entre estados emocionais e emoção, apesar de serem conceitos extremamente relacionados. Segundo Dias et al. (2013), as emoções são um constructo tão complexo e heterogêneo que a simples tentativa de encontrar uma definição que enquadre de forma adequada todas as abordagens teóricas existentes, e que as distinga claramente de constructos relacionados (como afeto, estados de humor e estados de ânimo), tem sido ingrata e decepcionante, gerando quase inevitavelmente controvérsia (ver também Engelmann, 1978).

\subsection{Avaliação dos estados emocionais no esporte}

Alguns estudos mostram relações entre estados emocionais, acessados com diferentes instrumentos, por diversos métodos e em várias modalidades, e fatores ligados ao esporte como: situação competitiva (Bray \& Martin, 2003); rendimento esportivo (Arruza, Balagué, \& Arrieta, 1998); desempenho de atletas no hóquei no gelo (M V Jones, Mace, \& Williams, 2000); fatores extracompetitivos no basquete (De Rose Junior, Korsakas, \& Deschamps, 1999); desempenho de atletas de basquete (Hoffmann, Bar-Eli, \& Tenenbaum, 1999); local do jogo e desempenho de atletas de rúgbi (Kerr \& Schaik, 1995); desempenho de atletas de caratê (McGowan \& Miller, 1989); comportamentos de adesão a tratamentos de lesão 
(Abenza, Olmedilla, Ortega, Ato, \& García-Mas, 2010); desempenho de atletas no beisebol (Friend \& LeUnes, 1990); carga de treinamento em nadadores (Morgan, Costill, Flynn, Raglin, \& O’Connor, 1988), desempenho no voleibol (Bueno \& Di Bonifácio, 2007; M. M. F. Da Silva et al., 2014; Di Bonifácio, 2013) e em praticantes de exercício (Frazier, 1988).

Para a pesquisa desses estados emocionais, mais precisamente dos estados de ânimo é necessário que haja instrumentos de avaliação adequados, aplicáveis em contextos esportivos e que deem respaldo à análise para se alcançar os objetivos traçados nos estudos sobre a influência dos estados de ânimo nos atletas. Há necessidade de estudos com diferentes modalidades esportivas analisando as variações dos estados de ânimo ao longo de períodos de treinamento pré-competitivos e durante as competições, já que estes estudos contribuirão para o conhecimento de como os atletas são afetados por ambos, como seus estados de ânimo se alteram nesse contexto e auxiliarão no planejamento dos treinamentos por parte dos treinadores (Torres-Luque, Hernández-García, Olmedilla, Toro, \& Vallejo, 2013). Além disso, contribuirão para a produção de conhecimento na área de Psicologia do Esporte, uma vez que a análise temporal dos estados de ânimo é algo ainda pouco explorada. Cerin, Szabo, Hunt e Williams (2000) argumentam que estudos das emoções no esporte devem ter o enfoque na descrição e no exame de estados emocionais complexos que permitam mostrar diferenças individuais e os fatores determinantes para a ocorrência dessas diferenças.

\subsubsection{Profile of Mood States}

Para o acesso aos estados de humor dos atletas, Torres-Luque et al. (2013) utilizaram o POMS (McNair et al., 1971; Morgan, 1980). Este instrumento foi originalmente elaborado para avaliar estados de humor de indivíduos que estavam em psicoterapia, mas é utilizado com frequência para identificar os efeitos psicológicos do treinamento e competição em atletas. O POMS é baseado em seis fatores: Raiva, Tensão, Depressão, Fadiga, Confusão e Vigor; sendo os cinco primeiros fatores negativos e o último fator positivo e tem sido usado 
como medição de predição do desempenho no esporte. Essa predição gerou o que se chama “perfil Iceberg” (Morgan, 1980), no qual os valores dos fatores negativos têm sua mensuração abaixo da norma da população e o valor do fator positivo acima dessa norma. No entanto, há muita controvérsia sobre se tal perfil é uma medida fidedigna relacionada à qualidade do desempenho de atletas em competição (Rowley, Landers, Kyllo, \& Etnier, 1995). Ainda assim, o POMS tem sido largamente utilizado em pesquisas sobre estados de humor em contexto esportivo e por psicólogos esportivos em suas atuações e intervenções.

Torres-Luque et al. (2013) analisaram a relação entre a evolução da carga de treinamento, dias de competição e estados de ânimo em judocas de elite durante um ciclo competitivo. Neste estudo, os autores avaliaram, com o POMS (McNair et al., 1971; Morgan, 1980), os estados de ânimo dos atletas no primeiro dia da semana de treinamento e no dia da competição, quando havia. Foi verificado um efeito do treinamento e das competições no ciclo competitivo em judocas de elite. Houve um incremento do fator Tensão nos dias das competições, assim como o incremento do fator Fadiga nas avaliações anteriores e posteriores a ambas as competições, coincidindo com o incremento do volume total de treinamento realizado. O fator Vigor (único positivo do POMS) não aumentou significativamente antes da competição. Neste estudo de Torres-Luque et al. (2013) a avaliação dos estados de ânimo se estendeu aos dias de treinamento e não se restringindo apenas aos dias de competição.

\subsubsection{Lista de Estados de Ânimo Presentes (LEAP)}

A LEAP desenvolvida por Engelmann (1986) é uma lista com quarenta locuções escritas na primeira pessoa do singular, que demonstram estados de ânimo, tendo ao lado de cada locução uma escala com graus de intensidade. Engelmann (1986) realizou um estudo empregando análise fatorial das locuções da LEAP, conforme o valor hedônico e o grau de ativação atribuído a elas pelos participantes, buscando mostrar uma característica de aproximação dos relatos verbais e suas correspondentes locuções de estados de ânimo 
presentes. Assim, as quarenta locuções foram distribuídas e agrupadas em doze fatores. Este instrumento permite a mensuração da presença de estados de ânimo do indivíduo no momento em que está sendo respondida.

Assume-se neste estudo o conceito de estado de ânimo proposto por Engelmann (1978, 1986, 2002) que é um estado subjetivo que, pode ser emocional (por exemplo, com raiva, alegre), ou pode ser não emocional (fome, cansado), portanto sendo um estado disjuntivo. Isto é, estado de ânimo é definido por dois ou mais atributos, sendo estado total (estado momentâneo de consciência nos quais o percepto todo aparece como uma gestalt única) ou estado bipartido interno (estado interno, dentro da pele que percebe). Este conceito de estado de ânimo é decorrente da definição de Nowlis (1965, p. 353) em que o estado de ânimo (mood, em inglês) é “o efeito em uma pessoa de suas próprias configurações de atividade. Tais configurações são padrões fundamentais de funcionamento e orientação (nível de ativação, nível de controle, nível de concentração, direção da orientação social e avaliação positiva ou negativa da situação)". Segundo Engelmann (1986), o conceito de estado de ânimo se aproxima do que se entende por sentimento na linguagem cotidiana.

\subsection{Estados de ânimo e futebol}

No futebol, os estados de ânimo dos jogadores também têm sido objeto de estudo. Nogueira (2009) descreveu o perfil dos estados de ânimo presentes, em função das posições exercidas por jovens atletas de futebol de campo e relacionados em função da fase da competição. Neste estudo, os resultados mostram um perfil anímico comum entre os atletas, com o emprego da LEAP (Engelmann, 1986), mas foram encontradas diferenças pré e pósjogo e estados de ânimo específicos das posições dos atletas, bem como a influência do resultado do jogo nos estados de ânimo pós-jogo. Os atletas de defesa mostraram uma prevalência de estados de prontidão, os meio campistas apresentaram estados de autocontrole 
e os atacantes mostraram-se mais concentrados e com o organismo em um processo de ativação.

Dias-Silva (2013), também no futebol, elaborou um Sistema de Categorias Comportamentais e relacionou tais categorias com estados de ânimo mensurados pela LEAP. Durante três partidas, três jogadores de diferentes posições foram observados e filmados durante o jogo. A partir dos vídeos, as subcategorias que se apresentaram, por meio das ações dos jogadores, foram descritas a cada 15 segundos numa folha de registros, permitindo a organização da frequência das categorias comportamentais. Os resultados do estudo de DiasSilva (2013) também mostraram um perfil comum de estados de ânimo presentes para todos os jogadores e um perfil específico para as posições, além da presença de posições que compartilharam estados de ânimo presentes. Os três grupos apresentaram um desempenho com altas frequências de categorias características à função exercida por sua posição e baixas frequências de categorias não relacionadas à suas funções. Os dados sugerem uma relação entre o estado de ânimo específico das posições e seu desempenho, uma vez que houve uma relação entre os dados de estados de ânimo presentes, obtidos com a LEAP (Engelmann, 1986) e o desempenho dos jogadores, obtido com o Sistema de Categorias Comportamentais.

Silva (2013) analisou o perfil dos estados de ânimo, no período pré-competição, de atletas de futebol que atuam em diferentes posições e verificou se este perfil é diferente dependendo do local do jogo (mandante ou visitante). Além disso, também investigou se houve relações entre os estados de ânimo pré-competitivos e o desempenho dos atletas durante a partida, sendo que para a avaliação do desempenho também fez uso do Sistema de Categorias Comportamentais proposto por Dias-Silva (2013). Os resultados obtidos por Silva (2013) reforçam dados obtidos em estudos com outras modalidades esportivas (Bueno \& Di Bonifácio, 2007, 2009; Di Bonifácio, 2006, 2013; Souza, 2011, 2014), em que, na condição pré-competição, atletas apresentam um perfil comum de estados de ânimo. Esse perfil foi 
verificado tantos nos jogos dentro quanto nos fora de casa. Foi verificado também um perfil específico das posições, que variou dependendo da localidade da disputa. No entanto, tais pesquisas se limitam à situação de jogo.

De la Vega Marcos et al. (2008) descreveram o perfil anímico de jogadores de futebol profissional avaliando-os com o POMS quatro eventos de pré-competição durante a fase de play-off de um campeonato nacional e não encontraram diferenças significativas nesse perfil entre o início e o fim do período compreendido entre o primeiro e o quarto evento, sugerindo uma estabilidade dos estados de ânimo ao longo do tempo numa mesma fase do campeonato.

Como já citado, o POMS (McNair et al., 1971; Morgan, 1980) se concentra em fatores negativos e para os objetivos do presente estudo é importante que se tenha acesso a aspectos tanto positivos quanto negativos e que permita uma análise mais ampla e completa. Para tanto, será utilizada a Lista de Estados de Ânimo Presentes - LEAP (Engelmann, 1986).

\section{JUSTIFICATIVA}

Embora os estados de ânimo pareçam estáveis, como os dados de De la Vega Marcos et al. (2008) sugerem, diferentes estímulos e contextos presentes como fase da competição, localidade, ambiente, contatos sociais, entre outros, podem modificar a intensidade e a valência desses estados (Bueno \& Di Bonifácio, 2007, 2009; Di Bonifácio, 2006, 2013; DiasSilva, 2013; Nogueira, 2009; R. C. da Silva, 2013; Souza, 2011). Além disso, há fenômenos psicológicos como decaimento, em que traços de informação perdem sua ativação devido, principalmente, à passagem do tempo (Brown, 1958; Ricker, Vergauwe, \& Cowan, 2014), e a expectativa, que é a espera pela ocorrência de um evento em um determinado tempo (Boltz, 1993). Alterações dos estados de ânimo em um determinado período de tempo devem ser estudadas para que se entenda como e quais aspectos podem influenciar essas mudanças, sobretudo em atletas num período competitivo esportivo. 


\section{OBJETIVO}

O presente estudo tem como objetivo examinar as alterações dos estados de ânimo em jovens atletas de futebol, separados por posição e função em campo, que ocorram num período competitivo, em função do decurso temporal. Assim, processos como decaimento dos estados de ânimo e a influência da expectativa poderão ser considerados, bem como a influência do contexto nas variações dos estados de ânimo. Para o acesso a esses dados, foram verificadas e examinadas as alterações dos estados de ânimo antes dos treinamentos e dos jogos de jovens atletas de futebol de base de um clube do interior do Estado de São Paulo utilizando a Lista de Estados de Ânimo Presentes - LEAP (Engelmann, 1986).

\section{MÉTODO E MATERIAIS}

\subsection{Participantes}

Participaram deste estudo 18 jogadores do sexo masculino com idade média de 15,4 anos (desvio-padrão $=0,266$ ) de uma equipe sub-15 de um clube de futebol do interior paulista. A equipe estava disputando a segunda fase de um campeonato de nível estadual durante a coleta de dados. Nessa fase do campeonato, 32 equipes foram divididas em oito grupos, sendo quatro equipes por grupo. As equipes de cada grupo jogaram em turno e returno, sendo três jogos como mandante e três jogos como visitante. Ao final dos seis jogos, as duas equipes com mais pontos no grupo passavam à próxima fase (play-offs) e as duas outras equipes do grupo eram eliminadas da competição. Os atletas participantes da pesquisa foram convocados para, pelo menos, três jogos dessa fase do campeonato e responderam à LEAP em todos os treinamentos do período de coleta de dados.

A diretoria do clube e os jogadores foram convidados para participarem da pesquisa por meio de um convite verbal após a autorização do Comitê de Ética em Pesquisa da Faculdade de Filosofia, Ciências e Letras de Ribeirão Preto (CAAE 36097414.0.0000.5407; $\mathrm{n}^{\mathrm{o}}$ do parecer 860.367). Para a participação no estudo, a diretoria autorizou, por escrito e 
rubricado, que o pesquisador realizasse a pesquisa nas dependências e com os atletas do clube. Os jogadores assinaram um Termo de Assentimento (Apêndice A) em que aceitaram colaborar voluntariamente à pesquisa, após um de seus responsáveis ter assinado um Termo de Consentimento Livre e Esclarecido (Apêndice B) autorizando o jogador a colaborar com o estudo, já que os participantes eram menores de idade.

\subsection{Materiais}

Foi utilizada a versão reduzida da LEAP (Engelmann, 1986) impressa em uma folha A4, juntamente com um formulário de instruções de preenchimento (Anexo A). Com o intuito de avaliar os estados de ânimo presentes dos sujeitos, Engelmann (1986) realizou uma série de trabalhos experimentais com sujeitos brasileiros em contextos brasileiros a fim de encontrar nos relatos verbais que denotassem esses estados subjetivos. A LEAP é uma lista com 40 locuções escritas na primeira pessoa do singular que demonstram diferentes estados de ânimo, tendo uma escala de intensidade ao lado dessas locuções. Essa lista foi obtida pela categorização de 536 palavras até se chegar à lista final com 40 locuções. O autor procedeu uma análise fatorial dessas 40 locuções agrupando-as conforme suas características de aproximação, de acordo com o valor hedônico e grau de ativação de cada locução. Foram utilizadas também canetas e pranchetas para o preenchimento do instrumento em quantidade suficiente para cada participante.

\subsection{Procedimento}

O pesquisador aplicou a LEAP cerca de 40 minutos antes de alguns treinamentos táticos/técnicos no Centro de Treinamento da equipe em local reservado para a aplicação; também aplicou o instrumento cerca de uma hora antes dos jogos de uma competição no vestiário nas dependências do local do jogo, antes da preleção. 
A aplicação da LEAP antes dos treinamentos foi feita em conformidade com o cronograma de treinamento da comissão técnica. Foi permitido o acesso aos últimos quatro jogos da segunda fase da competição e sete treinamentos da equipe, sendo as aplicações realizadas antes do último treinamento tático antecedente ao jogo (48 horas antes do jogo), antes do jogo propriamente dito e antes do primeiro treinamento subsequente ao jogo (48 horas depois do jogo).

A aplicação da LEAP se deu da seguinte forma: o pesquisador chegou ao local reservado para a coleta e aguardou que todos os participantes se acomodassem. A partir de então, o pesquisador entregou o instrumento e a folha de instruções a cada participante juntamente com a prancheta e a caneta. O pesquisador seguiu com o protocolo de aplicação explicando aos participantes a forma de preenchimento do instrumento, lendo em voz alta as instruções. Caso não houvesse questionamentos por parte dos sujeitos, o pesquisador autorizava o início do preenchimento. Caso houvesse, o pesquisador dirimia as dúvidas e seguia com o protocolo de coleta. Conforme os participantes terminavam seu preenchimento, o pesquisador recolhia as pranchetas, as canetas e as folhas. Ao término de todo o preenchimento, o pesquisador agradecia aos participantes e se retirava do local de coleta. As informações contidas na folha são sigilosas e somente o pesquisador teve acesso aos instrumentos respondidos durante o estudo.

\subsection{Forma de análise dos dados}

Foram calculados os valores de presença de cada Fator da LEAP em cada Evento para cada participante. Os 18 jogadores foram divididos em dois grupos: Ações Defensivas (AD) e Ações Ofensivas (AO). Essa divisão foi feita tendo em vista a função do jogador em campo em relação ao tipo de ação que é esperada na sua posição e que, consequentemente, o faz por mais tempo. Sendo assim, as posições goleiro, lateral, zagueiro e volante foram agrupadas no $\mathrm{AD}$ e as posições de meia-armador, meia-atacante, ponta e atacante foram agrupados no AO. 
O grupo $\mathrm{AD}$ possui 12 jogadores (dois goleiros, quatro zagueiros, quatro laterais e dois volantes) e o AO possui seis jogadores (um meia-armador, dois meias-atacantes, um ponta e dois atacantes).

Os dados foram coletados em três tipos de Eventos: antes do último treino antecedente ao jogo (condição Treino-Pré), antes do jogo (condição Pré-jogo) e antes do primeiro treino subsequente ao jogo (condição Treino-Pós). A distância temporal entre esses eventos é de 48 horas. A coleta aconteceu em 11 eventos, sendo quatro Treinos-Pré, quatro Pré-jogos e três Treinos-Pós. O período total da primeira coleta até a última foi de 22 dias.

Para a análise estatística, os dados foram calculados por meio do método da análise de variância (ANOVA) de medidas repetidas multivariadas modelo misto dos dados com os valores normalizados na nova escala. Utilizou-se o teste post hoc de Bonferroni quando diferença significativa foi detectada. Adotou-se como nível de significância $p \leq 0,05$. Para tanto, utilizou-se o software SPSS 20.0 para Windows.

Para que as comparações fossem equilibradas, o Treino-Pré 7 e o Jogo 4 não foram utilizados na análise estatística por não completarem a tríade que compõe a fonte de variação MOMENTO (ver definição a seguir) relacionada ao quarto jogo analisado pelo estudo, já que não houve treino após o Jogo 4 por conta da desclassificação da equipe no campeonato. Também se utilizou um recurso de substituição de valores nulos do software para um participante do grupo AD no Jogo 1, para um participante do grupo AO no Jogo 2 e para um participante do grupo AO no jogo 3. A substituição foi feita calculando-se a média dos pontos próximos de cada participante e atribuindo o valor obtido no lugar do valor nulo. Esse recurso foi utilizado para que a análise fosse feita com os 18 participantes, sem prejuízo de cálculo.

Foram observadas no modelo as variáveis, fontes de variação, o MOMENTO, que é o agrupamento do Treino-Pré, Pré-jogo e Treino-Pós referentes a um mesmo jogo (isto é, para o Jogo X, agrupou-se o Treino-Pré X, o Pré-jogo X e o Treino-Pós X); o EVENTO, que é o tipo 
de evento em si (Treino-Pré, Pré-jogo e Treino-Pós) e o GRUPO (Ações Defensivas e Ações Ofensivas).

\subsubsection{Cálculo das escalas e valores de presença dos Fatores da LEAP}

Os dados da LEAP (Engelmann, 1986) foram coletados com uma escala que varia de 1 (um) a 5 (cinco) absolutos em intensidade para cada locução. As locuções estão agrupadas em 12 (doze) Fatores e cada uma delas tem uma carga de correlação específica para cada Fator. As cargas de cada locução para cada Fator estão apresentadas na Tabela 1.

Para cada Fator, calculou-se um valor de presença, ou seja, se o estado de ânimo estava presente no momento da coleta de dados. Esse valor é a média ponderada das locuções de cada Fator, ou seja, multiplicou-se o valor na escala de cada locução da LEAP pela sua carga referente ao Fator. Esse procedimento foi repetido para cada Evento.

Não é comum procedimentos desse tipo com instrumentos escalares e separados por fatores. Na LEAP, cada locução tem um carga para cada Fator e uma locução pode estar correlacionada com mais de um Fator. Decidiu-se por fazer essa média ponderada para que cada locução tivesse seu real valor de importância em cada Fator, permitindo assim que os dados fossem analisados em nível Fatorial e não em nível de locução conforme os estudos de Bueno \& Di Bonifácio (2007, 2009); Dias-Silva (2013); Di Bonifácio (2006, 2013); Nogueira (2009); Silva (2013) e Souza $(2011,2014)$.

Tendo esse procedimento de análise em vista, verificou-se que os Fatores não estão equilibrados em termos de quantidade de locução (por exemplo, o Fator I possui 14 locuções correlacionadas, enquanto o Fator $\mathrm{V}$ apenas três) e que, portanto, suas amplitudes de escala seriam distintas, impossibilitando uma comparação. Sendo assim, as escalas de cada Fator foram ajustadas com um mesmo valor mínimo (zero) e máximo (um). 
Tabela 1. Representação das cargas de correlação de cada locução com o Fator (Tabela III, pp.142-43. Engelmann, 1986).

\begin{tabular}{|c|c|c|}
\hline FATOR & LOCUÇÃO & CARGA \\
\hline \multirow{14}{*}{$\begin{array}{c}\text { I } \\
\text { (Humilhação/Raiva) }\end{array}$} & Sinto-me humilhado & 0,67 \\
\hline & Sinto-me culpado & 0,66 \\
\hline & Sinto-me triste & 0,59 \\
\hline & Estou com medo & 0,53 \\
\hline & Estou sem graça & 0,52 \\
\hline & Sinto raiva & 0,51 \\
\hline & Estou com vergonha & 0,47 \\
\hline & Estou com inveja de alguém & 0,43 \\
\hline & Estou com nojo & 0,37 \\
\hline & Sinto ciúme de alguém & 0,32 \\
\hline & Sinto uma necessidade & 0,31 \\
\hline & Estou tomando cuidado & 0,28 \\
\hline & Tenho pena de alguém & 0,27 \\
\hline & Estou alegre & $-0,32$ \\
\hline \multirow{8}{*}{$\begin{array}{c}\text { II } \\
\text { (Fadiga) }\end{array}$} & Estou cansado & 0,73 \\
\hline & Estou com sono & 0,69 \\
\hline & Estou cheio & 0,63 \\
\hline & Sinto uma obrigação & 0,34 \\
\hline & Sinto-me triste & 0,33 \\
\hline & Estou com fome & 0,26 \\
\hline & Sinto um desejo & 0,26 \\
\hline & Estou alegre & $-0,29$ \\
\hline \multirow{8}{*}{$\begin{array}{c}\text { III } \\
(\text { Esperança) }\end{array}$} & Estou com esperança & 0,65 \\
\hline & Sinto saudade de alguém & 0,57 \\
\hline & Tenho pena de alguém & 0,50 \\
\hline & Sinto uma admiração por alguém & 0,48 \\
\hline & Sinto um desejo & 0,44 \\
\hline & Estou tomando cuidado & 0,43 \\
\hline & Sinto uma obrigação & 0,34 \\
\hline & Estou gostando de alguém & 0,32 \\
\hline \multirow{7}{*}{$\begin{array}{c}\text { IV } \\
\text { (Limerência/Empatia) }\end{array}$} & Estou gostando de alguém & 0,68 \\
\hline & Sinto atração sexual por alguém & 0,67 \\
\hline & Sinto ciúme de alguém & 0,60 \\
\hline & Sinto um desejo & 0,41 \\
\hline & Tenho saudade de alguém & 0,37 \\
\hline & Sinto uma admiração & 0,33 \\
\hline & Sinto-me orgulhoso & 0,32 \\
\hline \multirow{3}{*}{$\begin{array}{c}\mathrm{V} \\
\text { (Fisiológico) }\end{array}$} & Estou com calor & 0,82 \\
\hline & Estou com sede & 0,64 \\
\hline & Estou com frio & $-0,76$ \\
\hline
\end{tabular}


Tabela 1. Representação das cargas de correlação de cada locução com o Fator (Tabela III, pp.142-43. Engelmann, 1986).

\begin{tabular}{|c|c|c|}
\hline FATOR & LOCUÇÃO & CARGA \\
\hline \multirow{6}{*}{$\begin{array}{c}\text { VI } \\
\text { (Repulsa) }\end{array}$} & Acabo de levar um susto & 0,80 \\
\hline & Estou com nojo & 0,57 \\
\hline & Sinto-me surpreso & 0,39 \\
\hline & Sinto raiva & 0,27 \\
\hline & Estou com sede & 0,27 \\
\hline & Sinto um alívio & 0,26 \\
\hline \multirow{8}{*}{$\begin{array}{c}\text { VII } \\
\text { (Interesse) }\end{array}$} & Sinto-me interessado & 0,71 \\
\hline & Estou refletindo & 0,56 \\
\hline & Sinto um alívio & 0,41 \\
\hline & Sinto uma obrigação & 0,31 \\
\hline & Sinto-me orgulhoso & 0,3 \\
\hline & Sinto uma admiração por alguém & 0,29 \\
\hline & Estou tomando cuidado & 0,29 \\
\hline & Estou alegre & 0,25 \\
\hline \multirow{3}{*}{$\begin{array}{c}\text { VIII } \\
\text { (Surpresa) }\end{array}$} & Acho algo estranho & 0,60 \\
\hline & Sinto-me surpreso & 0,68 \\
\hline & Acho algo gozado & 0,60 \\
\hline \multirow{7}{*}{$\begin{array}{c}\text { IX } \\
\text { (Fome) }\end{array}$} & Estou com fome & 0,88 \\
\hline & Acho algo gozado & 0,49 \\
\hline & Estou alegre & 0,36 \\
\hline & Sinto um alívio & 0,35 \\
\hline & Estou com nojo & 0,33 \\
\hline & Sinto-me orgulhoso & 0,29 \\
\hline & Sinto uma obrigação & $-0,31$ \\
\hline \multirow{5}{*}{$\begin{array}{c}\mathrm{X} \\
(\text { Descaso/Inveja) }\end{array}$} & Faço pouco caso de alguém & 0,66 \\
\hline & Sinto inveja de alguém & 0,56 \\
\hline & Sinto-me orgulhoso & 0,38 \\
\hline & Estou com vergonha & 0,35 \\
\hline & Sinto uma obrigação & 0,33 \\
\hline \multirow{6}{*}{$\begin{array}{c}\text { XI } \\
\text { (Receptividade) }\end{array}$} & Estou aceitando alguma coisa & 0,65 \\
\hline & Sinto uma necessidade & 0,45 \\
\hline & Sinto-me orgulhoso & 0,34 \\
\hline & Sinto um desejo & 0,32 \\
\hline & Estou tomando cuidado & 0,28 \\
\hline & Sinto raiva & 0,26 \\
\hline \multirow{4}{*}{$\begin{array}{c}\text { XII } \\
\text { (Serenidade) }\end{array}$} & Estou conformado & 0,72 \\
\hline & Sinto-me calmo & 0,59 \\
\hline & Estou alegre & 0,26 \\
\hline & Estou tomando cuidado & $-0,34$ \\
\hline
\end{tabular}

Conclusão 
Esse ajuste está representado na Figura 1 e foi feito da seguinte forma: em cada Fator, para cálculo do valor máximo possível, multiplicou-se todas as suas cargas positivas por 5 (valor máximo da escala da LEAP) e suas cargas negativas por 1 (valor mínimo da escala da LEAP) e calculou-se a média dos valores obtidos, conforme o procedimento para cálculo de valor de presença. Para o valor mínimo foi feito o contrário: multiplicou-se as cargas positivas por 1 e as negativas por 5 e também calculou-se a média dos valores obtidos (A na Figura 1), obtendo-se a escala real (B na Figura 1). A partir daí, para ajustar à escala desejada, ajustou-se o valor mínimo obtido para 0 (zero) e o valor máximo para o valor correspondente ao tamanho da escala (C na Figura 1). Para que o valor máximo tivesse o valor de 1 (um), dividiu-se o valor máximo por ele mesmo. Sendo assim, o valor de presença obtido na escala original também foi dividido pelo valor máximo da escala, tendo assim o valor ajustado (D na Figura 1). Esse procedimento de normalização da escala foi feito para todos os valores de presença de todos os participantes em todos os eventos.

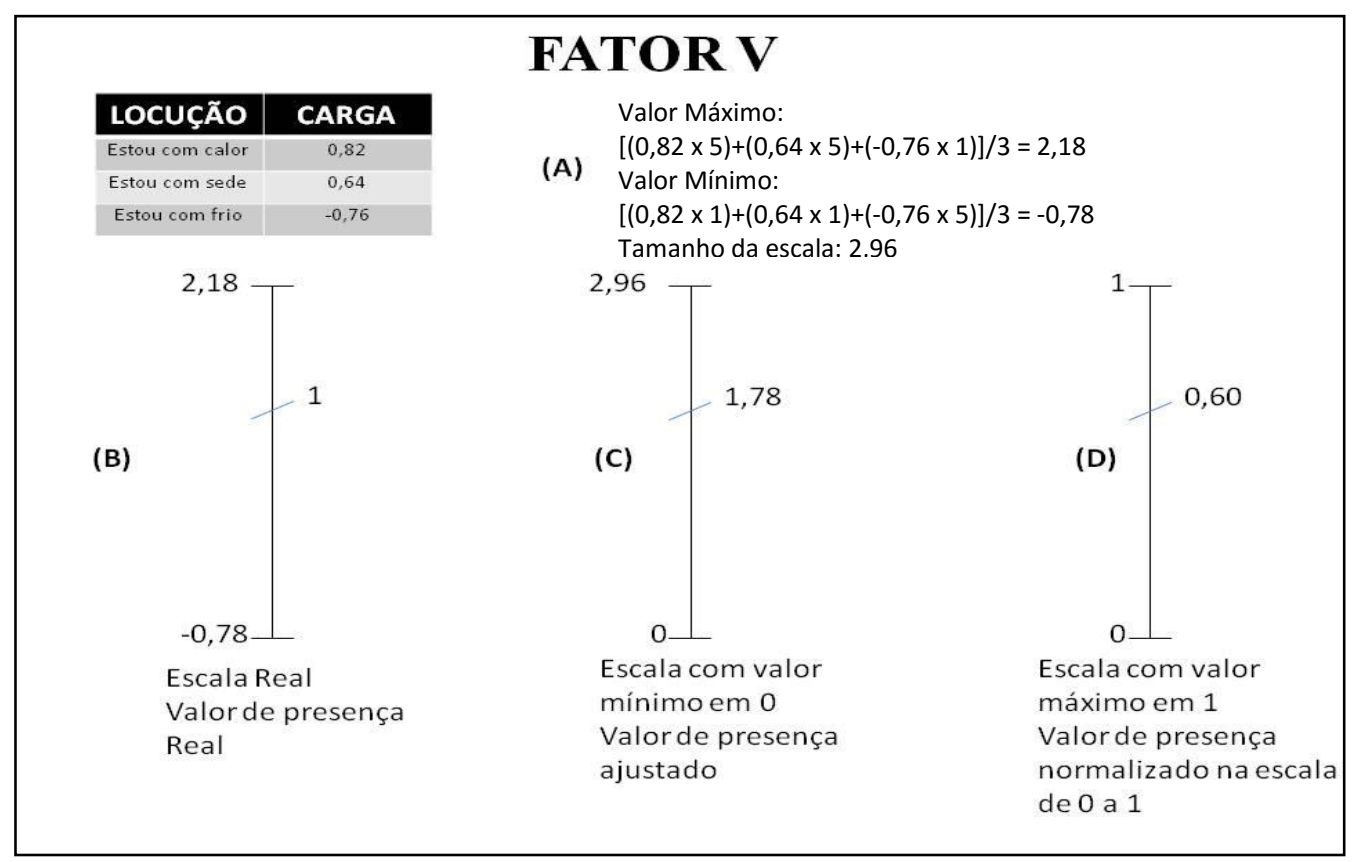

Figura 1. Representação do procedimento de ajuste das escalas e dos valores de presença dos Fatores. 


\section{RESULTADOS}

\subsection{Nomeação dos Fatores da LEAP}

A análise fatorial da LEAP proposta por Engelmann (1986) identificou quais locuções apresentam a mesma estrutura subjacente ou quais delas se aproximam. Os Fatores da LEAP representam os constructos que resumem os estados de ânimo observados. A principal função de uma análise fatorial é reduzir o número de variáveis que influenciam o fenômeno observado, tornando-o mais fácil de ser interpretado (Figueiredo Filho \& Silva Júnior, 2010).

Sendo assim, este trabalho propõe uma nomeação para os Fatores da LEAP levando em conta as locuções correlacionadas a cada um deles e suas respectivas cargas, com o intuito de facilitar a compreensão daquilo que o Fator representa. Assim, observando os Fatores representados na Tabela 1, propõe-se a seguinte nomeação:

Fator I - Humilhação/Raiva

Fator II - Fadiga

Fator III - Esperança

Fator IV - Limerência/Empatia

Fator V - Fisiológico

Fator VI - Repulsa

Fator VII - Interesse

Fator VIII - Surpresa

Fator IX - Fome

Fator X - Descaso/Inveja

Fator XI - Receptividade

Fator XII - Serenidade 


\subsection{Análise descritiva}

A equipe estava na $2^{\mathrm{a}}$ fase da competição durante a coleta. A coleta começou no Treino-Pré do $3^{\circ}$ jogo dessa fase do campeonato e se encerrou no Pré-jogo do $6^{\circ}$ jogo. Após esse jogo não houve treino, impossibilitando a coleta do $4^{\circ}$ Treino-Pós, decorrente da eliminação da equipe no campeonato e consequente dispensa dos jogadores da equipe.

A equipe jogou o $1^{\circ}$ e $3^{\circ}$ jogos do período de coleta $\left(3^{\circ}\right.$ e $5^{\circ}$ jogos da segunda fase do campeonato) como mandante e o $2^{\circ}$ e $4^{\circ}$ jogos do período de coleta como visitante $\left(4^{\circ}\right.$ e $6^{\circ}$ jogos da segunda fase do campeonato), sendo derrotada em todos os jogos do período, fazendo somente um gol no último jogo e sofrendo cinco gols no total dos quatro jogos.

Para a análise descritiva dos dados, tendo em vista os cálculos realizados para que as escalas pudessem ser comparadas, definiu-se níveis de presença dos valores obtidos. Foram considerados como nível de presença baixo os valores entre 0 e 0,3 de média, nível de presença médio entre 0,3 e 0,7 e nível de presença alto acima de 0,7.

As médias dos valores de presença de cada Fator da LEAP por GRUPO (média dos valores de presença de cada GRUPO durante a coleta), EVENTO (média dos valores de presença por tipo de EVENTO) e MOMENTO (média dos valores de presença em cada MOMENTO) estão na Tabela 2. Os Fatores I (Humilhação/Raiva), VI (Repulsa), VIII (Surpresa), IX (Fome) e X (Descaso/Inveja) apresentaram níveis de presença baixos durante todo o período do estudo Os Fatores II (Fadiga), III (Esperança), IV (Limerência/Empatia), V (Fisiológico), VII (Interesse), XI (Receptividade) e XII (Serenidade) apresentaram níveis de presença médios durante todo o período do estudo. Nenhum Fator da LEAP apresentou nível de presença alto durante o período do estudo. 
Tabela 2. Média dos valores de presença de cada Fator da LEAP divididos por grupo, evento e momento.

\begin{tabular}{|c|c|c|c|c|c|c|c|c|}
\hline \multirow[b]{3}{*}{ FATOR } & \multicolumn{8}{|c|}{ MÉDIAS } \\
\hline & \multicolumn{2}{|c|}{ GRUPO } & \multicolumn{3}{|c|}{ EVENTO } & \multicolumn{3}{|c|}{ MOMENTO } \\
\hline & $\begin{array}{c}\text { AÇÕES } \\
\text { DEFENSIVAS }\end{array}$ & $\begin{array}{c}\text { AÇÕES } \\
\text { OFENSIVAS }\end{array}$ & $\begin{array}{l}\text { TREINO } \\
\text { PRÉ }\end{array}$ & JOGO & $\begin{array}{l}\text { TREINO } \\
\text { PÓS }\end{array}$ & 1 & 2 & 3 \\
\hline I & 0,245 & 0,244 & 0,246 & 0,211 & 0,278 & 0,231 & 0,242 & 0,261 \\
\hline II & 0,305 & 0,335 & 0,331 & 0,273 & 0,357 & 0,344 & 0,312 & 0,304 \\
\hline III & 0,489 & 0,544 & 0,545 & 0,539 & 0,465 & 0,598 & 0,490 & 0,461 \\
\hline IV & 0,431 & 0,484 & 0,487 & 0,446 & 0,440 & 0,506 & 0,429 & 0,439 \\
\hline V & 0,506 & 0,500 & 0,486 & 0,370 & 0,654 & 0,525 & 0,512 & 0,472 \\
\hline VI & 0,154 & 0,180 & 0,165 & 0,156 & 0,179 & 0,167 & 0,164 & 0,169 \\
\hline VII & 0,431 & 0,463 & 0,479 & 0,485 & 0,376 & 0,507 & 0,401 & 0,433 \\
\hline VIII & 0,212 & 0,258 & 0,245 & 0,224 & 0,235 & 0,282 & 0,217 & 0,206 \\
\hline IX & 0,234 & 0,270 & 0,283 & 0,237 & 0,237 & 0,281 & 0,242 & 0,234 \\
\hline $\mathrm{X}$ & 0,225 & 0,230 & 0,245 & 0,228 & 0,210 & 0,249 & 0,220 & 0,213 \\
\hline XI & 0,365 & 0,395 & 0,426 & 0,391 & 0,323 & 0,462 & 0,328 & 0,350 \\
\hline XII & 0,304 & 0,414 & 0,387 & 0,369 & 0,321 & 0,367 & 0,331 & 0,378 \\
\hline
\end{tabular}

\subsection{Análise estatística}

\section{Fator I - Humilhação/Raiva}

Foi encontrada diferença significativa $(\mathrm{p}=0,013)$ entre os EVENTOS Pré-jogo (média 0,211; erro-padrão 0,029) e Treino-Pós (média 0,278; erro-padrão 0,035) independente do MOMENTO e do GRUPO.

Isto é, observando a Figura 2, para ambos os GRUPOS e em todos os MOMENTOS, o valor de presença no Pré-jogo foi significativamente mais baixo se comparado ao Treino-Pós. O valor de presença no Treino-Pré não apresentou diferença significativa se comparado aos outros dois tipos de EVENTOS, sendo um valor intermediário entre o valor do Pré-jogo e o valor do Treino-Pós. Ainda que a diferença não tenha sido significativa, a média do valor de presença para o Treino-Pré foi mais alto que o Pré-jogo em todos os MOMENTOS e para ambos os GRUPOS. 


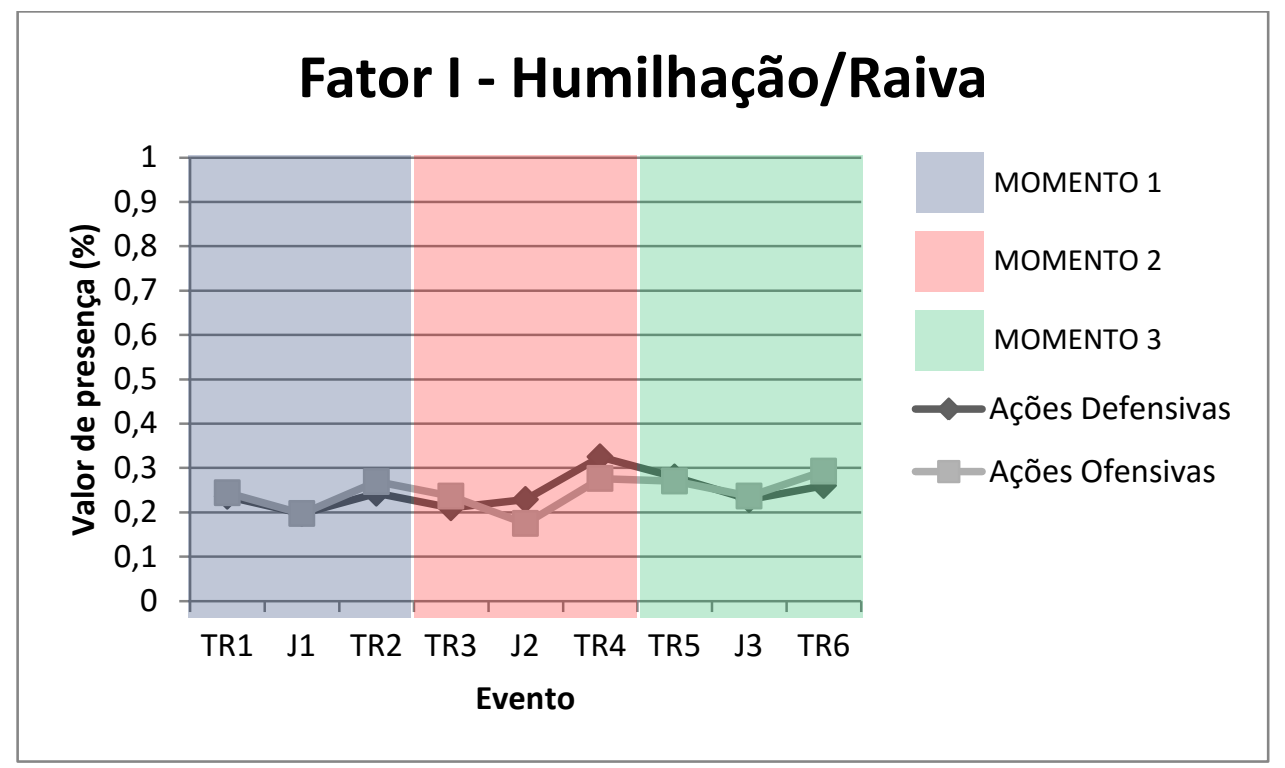

Figura 2. Médias dos grupos no Fator I (Humilhação/Raiva) da LEAP em cada evento. TR1: Treino-Pré 1. TR3: Treino-Pré 2. TR5: Treino-Pré 3. J1: Pré-jogo 1. J2: Pré-jogo 2. J3: Préjogo 3. TR2: Treino-Pós 1. TR4: Treino-Pós 2. TR6: Treino-Pós 3.

\section{Fator II - Fadiga}

Foram encontradas duas diferenças significativas: entre os EVENTOS Treino-Pré (média 0,331; erro-padrão 0,027) e Pré-jogo (média 0,273; erro-padrão 0,028), sendo p=0,001; e Préjogo (média 0,273; erro-padrão 0,028) e Treino-Pós (média 0,357; erro-padrão 0,032), sendo $\mathrm{p}=0,002$

Foi encontrada também a interação entre MOMENTO e GRUPO. A diferença significativa observada foi para o GRUPO AD, em que os MOMENTOS tiveram padrões de alteração distintos. Para o GRUPO AD, o MOMENTO 2 (média 0,328; erro-padrão 0,026) foi significativamente diferente do 3 (média 0,272; erro-padrão 0,021), sendo p=0,035. Essa diferença não foi encontrada no GRUPO AO, como pode ser observado na Figura 3. 


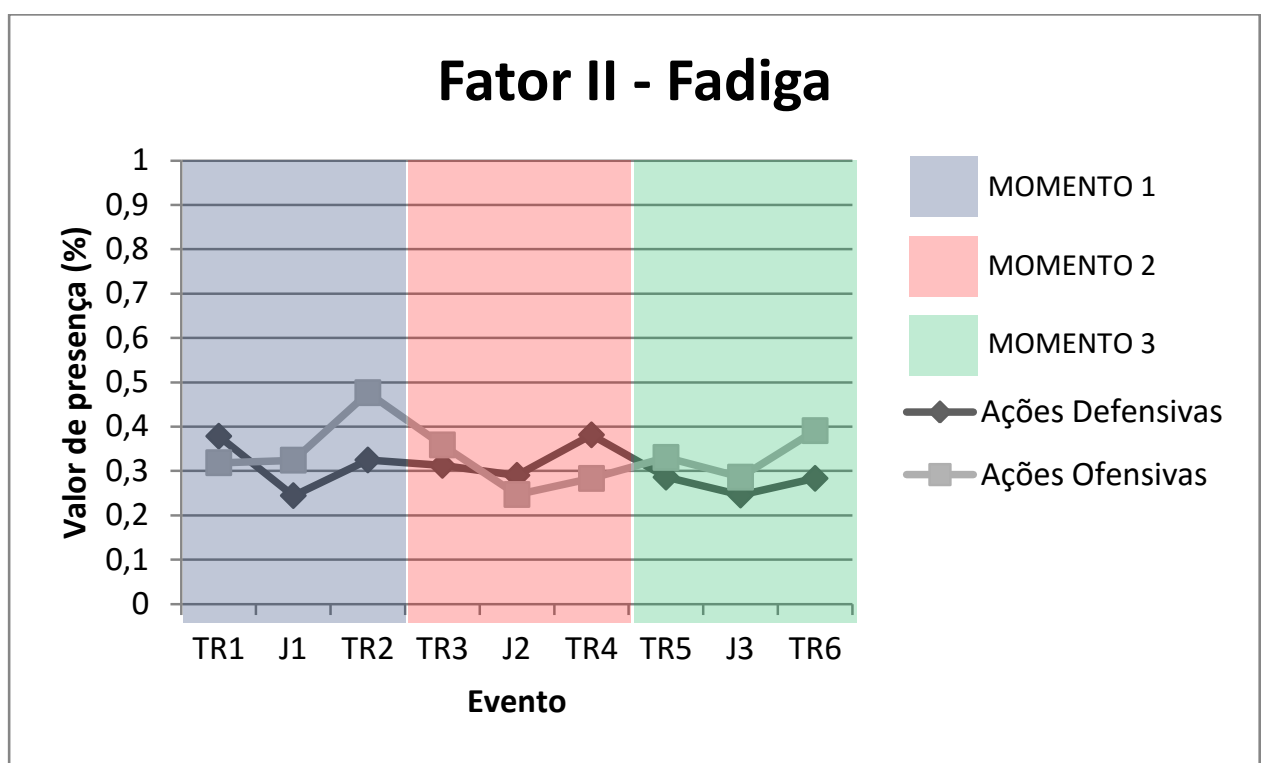

Figura 3. Médias dos grupos no Fator II (Fadiga) da LEAP em cada evento. TR1: Treino-Pré 1. TR3: Treino-Pré 2. TR5: Treino-Pré 3. J1: Pré-jogo 1. J2: Pré-jogo 2. J3: Pré-jogo 3. TR2: Treino-Pós 1. TR4: Treino-Pós 2. TR6: Treino-Pós 3.

\section{Fator III - Esperança}

Constatou-se diferença significativa entre os EVENTOS Treino-Pré (média 0,545; erro-padrão 0,039) e Treino-Pós (média 0,465; erro-padrão 0,048), sendo p=0,001. Foi encontrada diferença significativa entre os MOMENTOS 1 (média 0,598; erro-padrão 0,035) e 2 (média 0,490; erro-padrão 0,039), sendo $\mathrm{p}=0,000$. Também foi encontrada diferença significativa entre os MOMENTOS 1 (média 0,598; erro-padrão 0,035) e 3 (média 0,461; erro-padrão 0,050), sendo p=0,002. Não foi constatada diferença entre MOMENTOS 2 e 3.

Encontrou-se também interação entre MOMENTO e EVENTO neste Fator da LEAP. Isto é, essas fontes de variação se interdependem, sendo que uma alteração em uma afeta a outra ou então que há diferença no padrão de alteração delas conforme a mudança de outra.

Com isso, encontrou-se diferença significativa no valor de presença de um EVENTO a outro dentro de um mesmo MOMENTO: Para o MOMENTO 1, os EVENTOS Treino-Pré (média 0,670; erro-padrão 0,039) e Treino-Pós (média 0,475; erro-padrão 0,047) foram significativamente diferentes, sendo $\mathrm{p}=0,000$; também houve diferença significativa entre os 
EVENTOS Pré-jogo (média 0,616; erro-padrão 0,035) e Treino-Pós (média 0,475; erropadrão 0,047 ), sendo $\mathrm{p}=0,027$, no mesmo MOMENTO. Para o MOMENTO 2, foi encontrada diferença significativa entre os EVENTOS Treino-Pré (média 0,539; erro-padrão 0,038) e Treino-Pós (média 0,422; erro-padrão 0,046), sendo p=0,008. Para o MOMENTO 3, foi encontrada diferença significativa entre os EVENTOS Treino-Pré (média 0,403; erro-padrão 0,042) e Pré-jogo (média 0,454; erro-padrão 0,056), sendo p=0,002.

Assim, no contexto do primeiro jogo, o valor de presença desse Fator da LEAP caiu no Treino-Pós para ambos os grupos em comparação aos outros dois EVENTOS. No contexto do segundo jogo, o valor de presença caiu significativamente do Treino-Pré para o TreinoPós, sendo que o valor de presença no Pré-jogo foi intermediário em comparação a esses EVENTOS significativamente diferentes. No contexto do terceiro jogo, o valor de presença aumentou no Pré-jogo se comparado ao Treino-Pré. O valor de presença no Treino-Pós caiu em comparação ao Pré-jogo, ainda que o valor obtido tenha sido maior que o Treino-Pré (Figura 4).

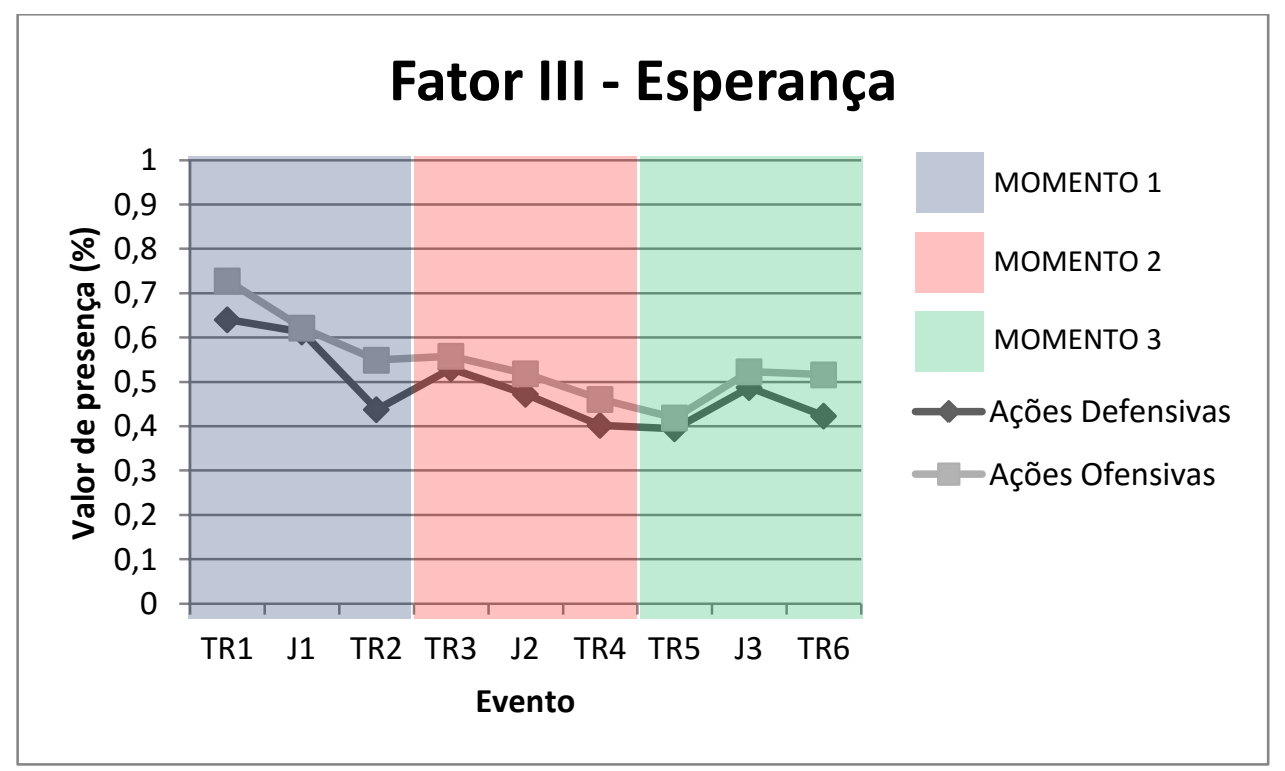

Figura 4. Médias dos grupos no Fator III (Esperança) da LEAP em cada evento. TR1: TreinoPré 1. TR3: Treino-Pré 2. TR5: Treino-Pré 3. TR7: Treino-Pré 4. J1: Pré-jogo 1. J2: Pré-jogo 2. J3: Pré-jogo 3. J4: Pré-jogo 4. TR2: Treino-Pós 1. TR4: Treino-Pós 2. TR6: Treino-Pós 3. 
Na comparação dos mesmos tipos de EVENTOS em diferentes MOMENTOS, encontrou-se diferença significativa no valor de presença, ou seja, dependendo do MOMENTO, o valor de presença para os tipos de EVENTO não é o mesmo. Para o EVENTO Treino-Pré, encontrou-se diferença significativa entre os MOMENTOS 1 (média 0,670; erropadrão 0,039) e 2 (média 0,539; erro-padrão 0,038), sendo p=0,001; entre os MOMENTOS 1 (média 0,670; erro-padrão 0,039) e 3 (média 0,403; erro-padrão 0,042), sendo p=0,000; e entre os MOMENTOS 2 (média 0,539; erro-padrão 0,038) e 3 (média 0,403; erro-padrão 0,042), sendo $p=0,000$. Para o EVENTO Pré-jogo, constatou-se diferença significativa entre os MOMENTOS 1 (média 0,616; erro-padrão 0,035) e 2 (média 0,488; erro-padrão 0,039), sendo p=0,001; e entre os MOMENTOS 1 (média 0,616; erro-padrão 0,035) e 3 (média 0,499; erro-padrão 0,045), sendo p=0,039. O EVENTO Treino-Pós não teve diferença significativa constatada em nenhum MOMENTO.

\section{Fator IV - Limerência/Empatia}

Foi encontrada diferença significativa $(p=0,012)$ entre os MOMENTOS 1 (média 0,506; erro-padrão 0,050) e 2 (média 0,429; erro-padrão 0,051), independentemente do EVENTO e do GRUPO.

Isto é, o padrão de alteração nos EVENTOS foi o mesmo, mas do MOMENTO 1 para o 2, o valor de presença ficou mais baixo, na média, para ambos os grupos, conforme pode ser visto na Figura 5. O MOMENTO 3 tem média 0,439 com erro-padrão 0,062, portanto um valor bem próximo do MOMENTO 2, ainda que não apresente diferença significativa na comparação com o MOMENTO 1. 


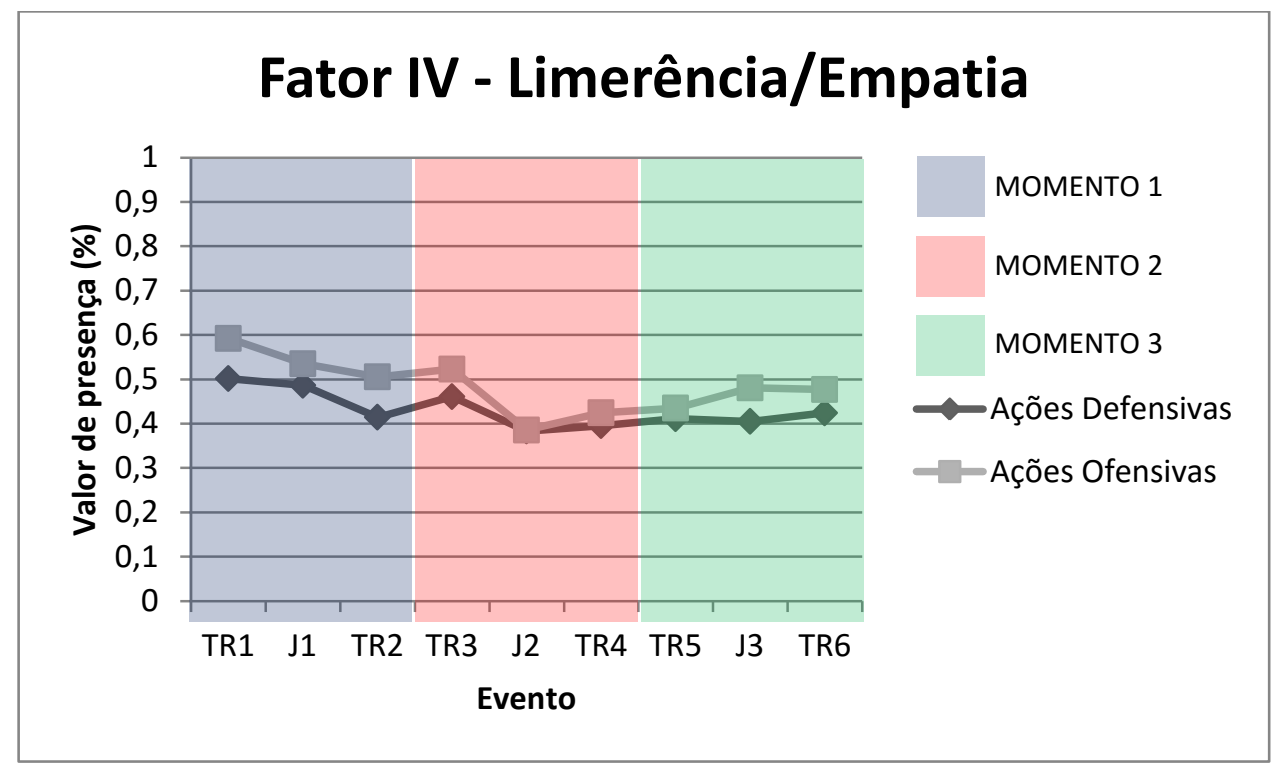

Figura 5. Médias dos grupos no Fator IV (Limerência/Empatia) da LEAP em cada evento. TR1: Treino-Pré 1. TR3: Treino-Pré 2. TR5: Treino-Pré 3. TR7: Treino-Pré 4. J1: Pré-jogo 1. J2: Pré-jogo 2. J3: Pré-jogo 3. J4: Pré-jogo 4. TR2: Treino-Pós 1. TR4: Treino-Pós 2. TR6: Treino-Pós 3.

\section{Fator V - Fisiológico}

Foi encontrada diferença significativa para esse Fator da LEAP entre os EVENTOS Treino-Pré (média 0,486; erro-padrão 0,029) e Pré-jogo (média 0,370; erro-padrão 0,016), sendo p=0,007; Treino-Pré (média 0,486; erro-padrão 0,029) e Treino-Pós (média 0,654; erropadrão 0,038 ), sendo $\mathrm{p}=0,001$; e Pré-jogo (média 0,370; erro-padrão 0,016) e Treino-Pós (média 0,654; erro-padrão 0,038), sendo p=0,001.

Encontrou-se também interação entre MOMENTO e EVENTO neste Fator da LEAP. Isto é, essas fontes de variação se interdependem, sendo que uma alteração em uma depende da outra ou então que há diferença no padrão de alteração delas conforme a mudança de outra.

Assim, encontrou-se diferença significativa no valor de presença de um EVENTO a outro dentro de um mesmo MOMENTO: Para o MOMENTO 1, os EVENTOS Pré-jogo (média 0,524; erro-padrão 0,042) e Treino-Pós (média 0,605; erro-padrão 0,044), sendo $\mathrm{p}=0,002$, foram significativamente diferentes. Para o MOMENTO 2, os EVENTOS Treino- 
Pré (média 0,620; erro-padrão 0,050) e Pré-jogo (média 0,272; erro-padrão 0,025), sendo p=0,000; e os EVENTOS Pré-jogo (média 0,272; erro-padrão 0,025) e Treino-Pós (média 0,636; erro-padrão 0,040), sendo $\mathrm{p}=0,000$, foram significativamente diferentes. Para o MOMENTO 3, os EVENTOS Treino-Pré (média 0,318; erro-padrão 0,039) e Treino-Pós (média 0,726; erro-padrão 0,042), sendo p=0,000; e os EVENTOS Pré-jogo (média 0,381; erro-padrão 0,029) e Treino-Pós (média 0,726; erro-padrão 0,042), sendo p=0,000, foram significativamente diferentes.

Com isso, para ambos os grupos, o valor de presença deste Fator da LEAP no TreinoPós no contexto do primeiro jogo foi maior se comparado ao Pré-jogo (Figura 6). O valor no Treino-Pré foi intermediário aos valores encontrados nos outros dois eventos, sem diferença significativa para ambos. No contexto do segundo jogo, o valor de presença no Pré-jogo caiu se comparado ao valor no Treino-Pré. No Treino-Pós, o valor de presença aumentou se comparado ao valor no Pré-jogo. Os valores encontrados no Treino-Pré e Treino-Pós são semelhantes, sendo os dois maiores que o valor no Pré-jogo nesse contexto. Para o contexto do terceiro jogo, o valor de presença obtido no Treino-Pós foi maior se comparado aos outros dois EVENTOS. Tanto o valor no Treino-Pré quanto no Pré-jogo foram semelhantes nesse contexto.

Na comparação dos mesmos tipos de EVENTOS em diferentes MOMENTOS, encontrou-se diferença significativa no valor de presença, ou seja, dependendo do MOMENTO, o valor de presença para os tipos de EVENTO não é regular. Para o EVENTO Treino-Pré, os MOMENTOS 1 (média 0,524; erro-padrão 0,042) e 3 (média 0,318; erropadrão 0,039), sendo p=0,006; e os MOMENTOS 2 (média 0,620; erro-padrão 0,050) e 3 (média 0,318 ; erro-padrão 0,039 ), sendo $\mathrm{p}=0,002$, foram significativamente diferentes. Para o EVENTO Pré-jogo, os MOMENTOS 1 (média 0,456; erro-padrão 0,023) e 2 (média 0,272; erro-padrão 0,025), sendo p=0,001; e os MOMENTOS 2 (média 0,272; erro-padrão 0,025) e 3 
(média 0,381; erro-padrão 0,029), sendo $\mathrm{p}=0,037$, foram significativamente diferentes. Para o EVENTO Treino-Pós, os MOMENTOS 1 (média 0,605; erro-padrão 0,044) e 3 (média 0,726; erro-padrão 0,042), sendo $\mathrm{p}=0,022$, foram significativamente diferentes.

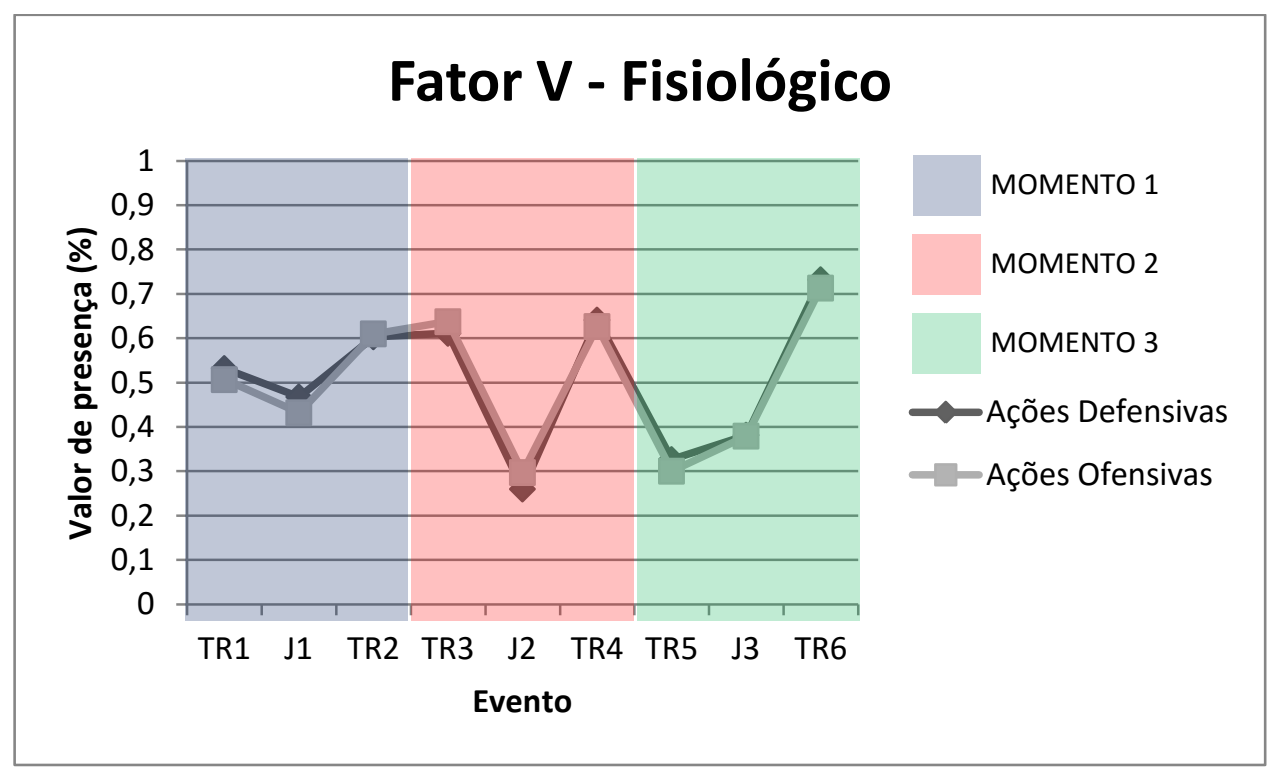

Figura 6. Médias dos grupos no Fator V (Fisiológico) da LEAP em cada evento. TR1: Treino-Pré 1. TR3: Treino-Pré 2. TR5: Treino-Pré 3. TR7: Treino-Pré 4. J1: Pré-jogo 1. J2: Pré-jogo 2. J3: Pré-jogo 3. J4: Pré-jogo 4. TR2: Treino-Pós 1. TR4: Treino-Pós 2. TR6: Treino-Pós 3.

Tendo em vista o Treino-Pré, a média do valor de presença deste Fator da LEAP no contexto do terceiro jogo foi maior se comparado aos valores encontrados nos outros dois contextos (Figura 6). No contexto do primeiro jogo, foi encontrado o menor valor de presença desse Fator para esse EVENTO. O valor no Pré-jogo foi menor no contexto do segundo jogo se comparado aos outros dois contextos. Apesar de não serem significativamente diferentes, o valor de presença no contexto do primeiro jogo foi maior que o valor encontrado no contexto do terceiro jogo. Para o Treino-Pós, o valor de presença do Fator foi maior no contexto do terceiro jogo se comparado ao valor obtido no contexto do primeiro jogo. O valor no contexto do segundo jogo foi próximo do valor encontrado no contexto do primeiro jogo. No entanto, não foi possível verificar um padrão geral de alteração dos valores de presença para este 
Fator, visto que cada condição de EVENTO relacionado a um MOMENTO teve um padrão específico de alteração.

\section{Fator VI - Repulsa}

Foi constatada interação entre MOMENTO, EVENTO e GRUPO para esse Fator da LEAP. Isto significa que não há um padrão geral de alteração dos valores de presença, sendo que cada mudança em um fator de variação das variáveis modifica sua forma de alteração (Figura 7).

Pelo tamanho da amostra deste estudo, não é possível fazer uma análise mais detalhada dessa interação. Como não houve diferença significativa em nenhum nível hierárquico menor, isto é, diferenças dentro dos fatores de variação ou interação entre dois desses três fatores, não é possível descrever um padrão geral de alteração levando-se em conta esses fatores de variação (GRUPO, MOMENTO e EVENTO) das variáveis desse estudo.

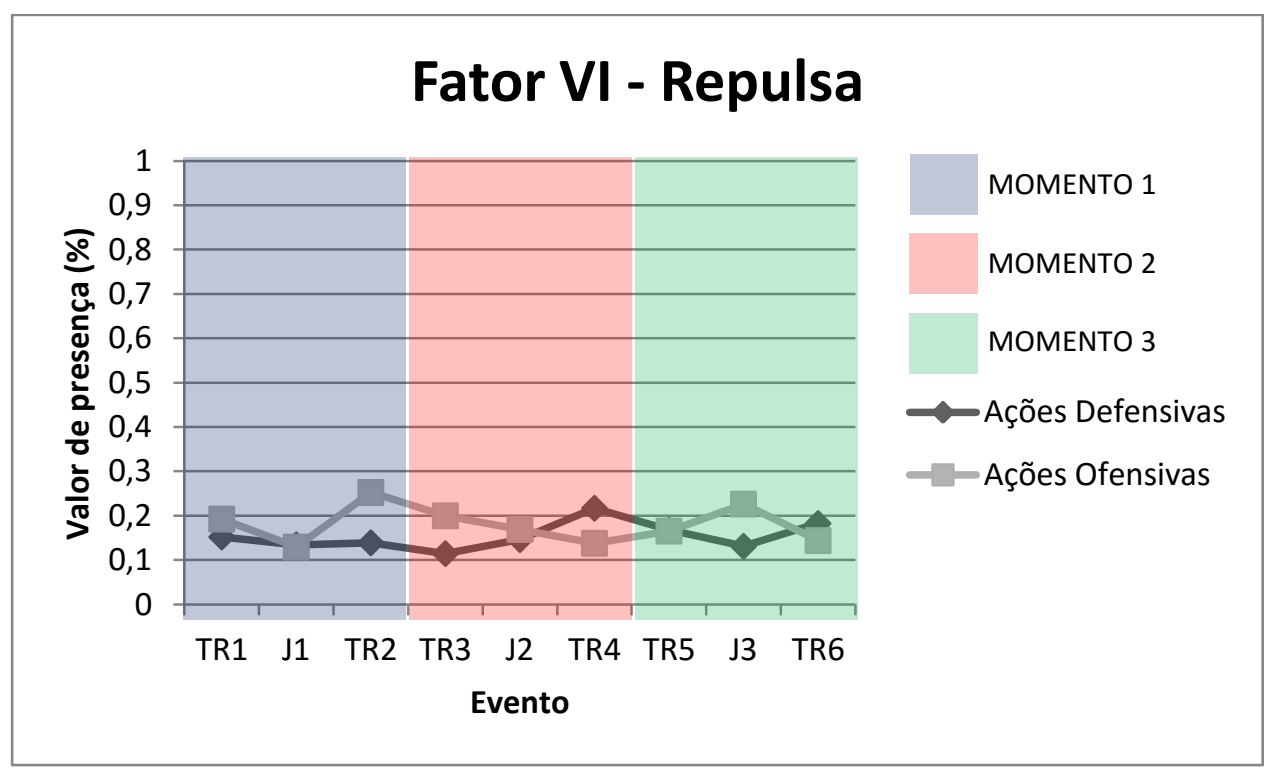

Figura 7. Médias dos grupos no Fator VI (Repulsa) da LEAP em cada evento. TR1: TreinoPré 1. TR3: Treino-Pré 2. TR5: Treino-Pré 3. TR7: Treino-Pré 4. J1: Pré-jogo 1. J2: Pré-jogo 2. J3: Pré-jogo 3. J4: Pré-jogo 4. TR2: Treino-Pós 1. TR4: Treino-Pós 2. TR6: Treino-Pós 3. 
Fator VII - Interesse

Foi encontrada diferença entre os EVENTOS Treino-Pré (média 0,479; erro-padrão 0,033) e Treino-Pós (média 0,376; erro-padrão 0,035), sendo p=0,008 e entre os EVENTOS Pré-jogo (média 0,485; erro-padrão 0,032) e Treino-Pós (média 0,376; erro-padrão 0,035), sendo $\mathrm{p}=0,000$. Também foi encontrada diferença significativa $(\mathrm{p}=0,003)$ entre os MOMENTOS 1 (média 0,507; erro-padrão 0,024) e 2 (média 0,401; erro-padrão 0,033) Foi encontrada uma diferença com valor de p próximo do critério/marginal $(\mathrm{p}=0,055)$ entre os MOMENTOS 1 (média 0,507; erro-padrão 0,024) e 3 (média 0,433; erro-padrão 0,039). Ambas as diferenças independem do GRUPO (Figura 8).

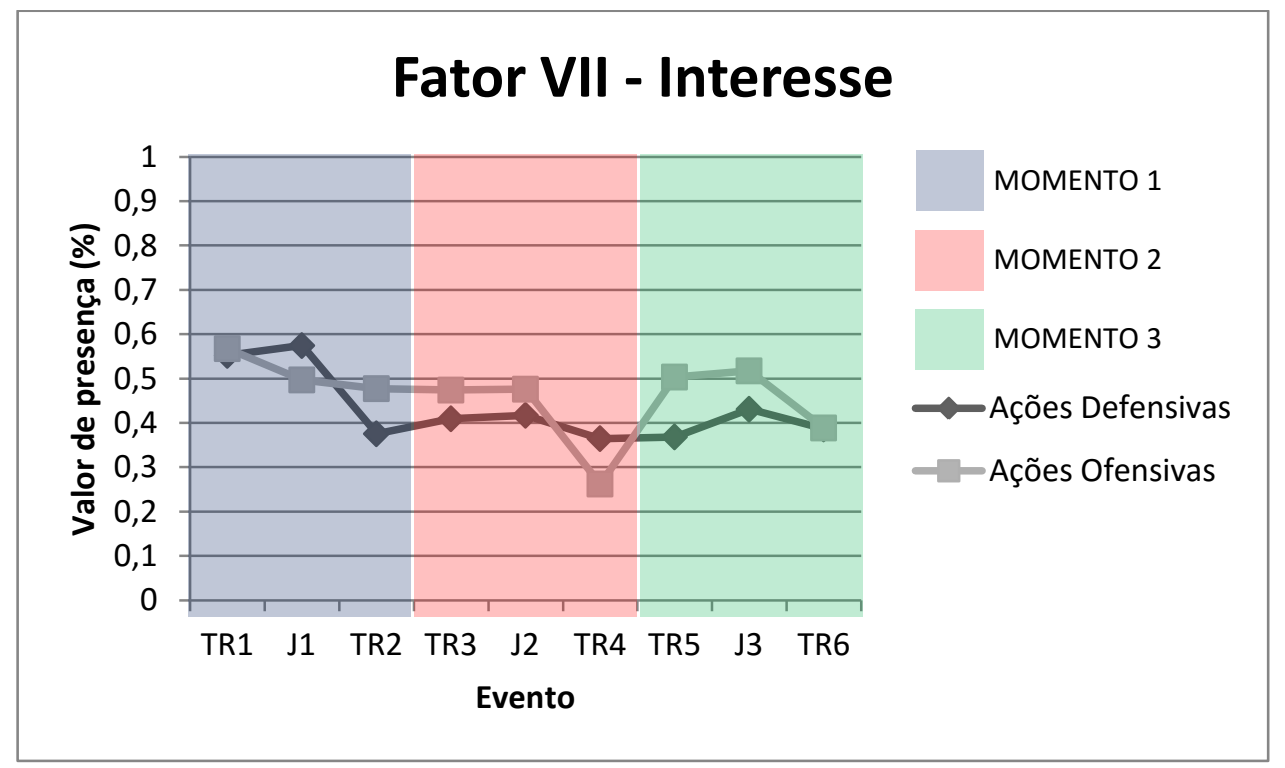

Figura 8. Médias dos grupos no Fator VII (Interesse) da LEAP em cada evento. TR1: TreinoPré 1. TR3: Treino-Pré 2. TR5: Treino-Pré 3. TR7: Treino-Pré 4. J1: Pré-jogo 1. J2: Pré-jogo 2. J3: Pré-jogo 3. J4: Pré-jogo 4. TR2: Treino-Pós 1. TR4: Treino-Pós 2. TR6: Treino-Pós 3.

\section{Fator VIII - Surpresa}

Encontrou-se uma interação entre MOMENTO e GRUPO para esse Fator da LEAP. A diferença significativa ( $\mathrm{p}=0,043$ ) foi observada para o GRUPO AO entre os MOMENTOS 1 (média 0,355; erro-padrão 0,052) e 3 (média 0,204; erro-padrão 0,033). Isto é, para o GRUPO 
AO, a média dos valores de presença dos EVENTOS foi menor no contexto do terceiro jogo se comparado ao primeiro (Figura 9).

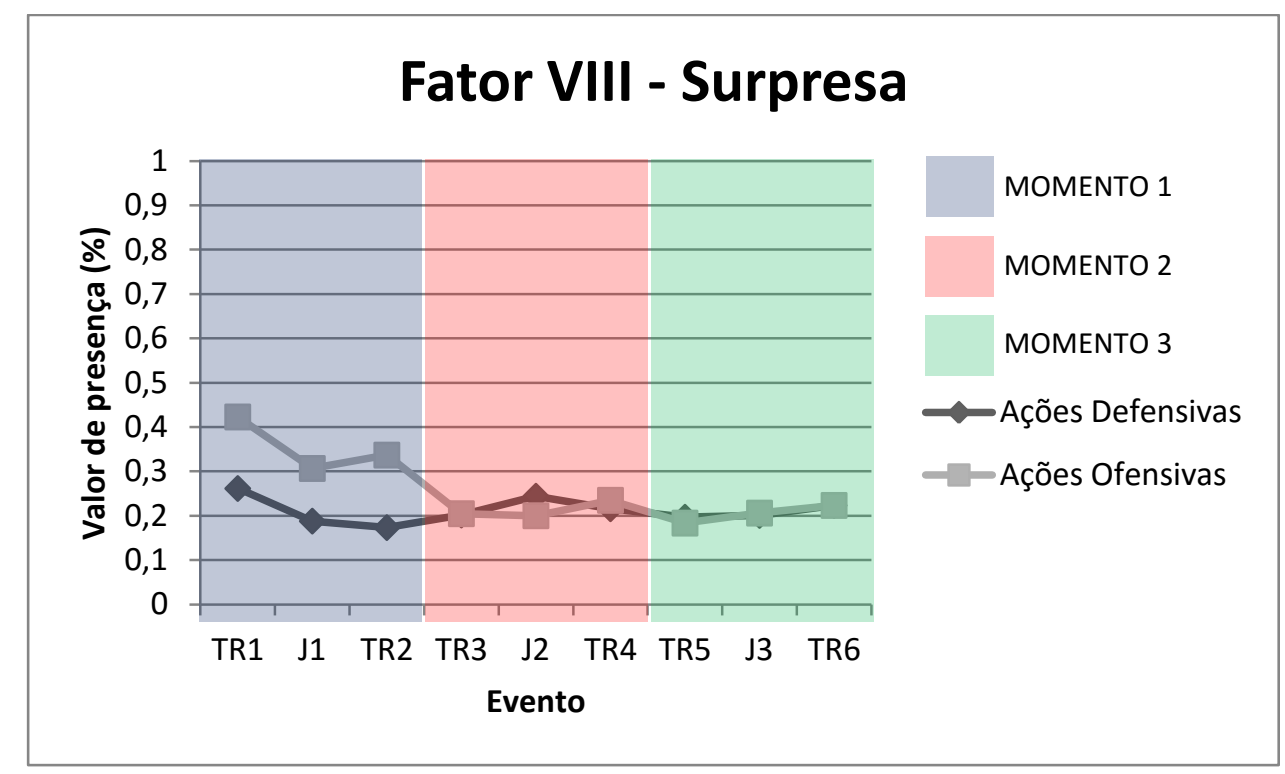

Figura 9. Médias dos grupos no Fator VIII (Surpresa) da LEAP em cada evento. TR1: Treino-Pré 1. TR3: Treino-Pré 2. TR5: Treino-Pré 3. TR7: Treino-Pré 4. J1: Pré-jogo 1. J2: Pré-jogo 2. J3: Pré-jogo 3. J4: Pré-jogo 4. TR2: Treino-Pós 1. TR4: Treino-Pós 2. TR6: Treino-Pós 3.

\section{Fator IX - Fome}

Foi encontrada diferença significativa $(\mathrm{p}=0,024)$ entre os EVENTOS Treino-Pré (Média 0,283; erro-padrão 0,016) e Pré-jogo (média 0,237; erro-padrão 0,020), independentemente do MOMENTO e do GRUPO (Figura 10). Ou seja, o valor de presença cai no Pré-jogo se comparado ao Treino-Pré e se mantém no Treino-Pós, apesar de esse valor não ter sido considerado significativamente diferente do valor no Treino-Pré. 


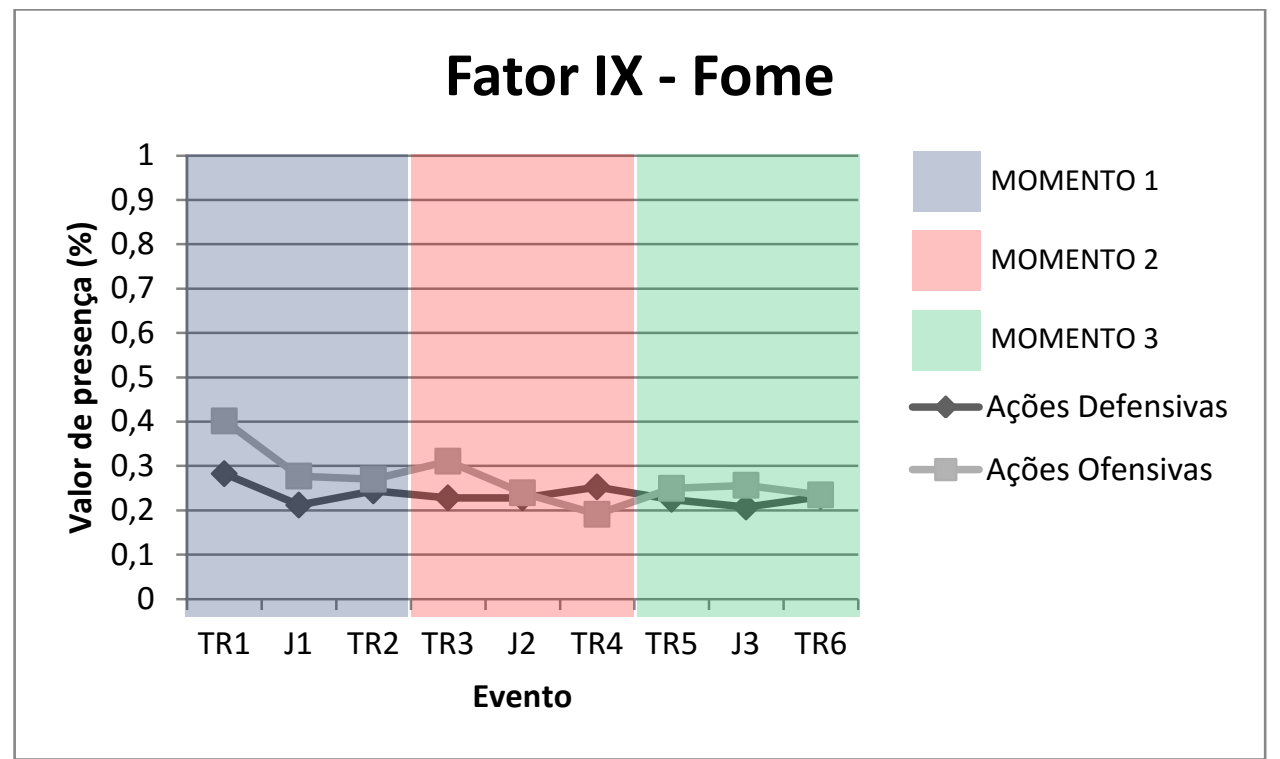

Figura 10. Médias dos grupos no Fator IX (Fome) da LEAP em cada evento. TR1: TreinoPré 1. TR3: Treino-Pré 2. TR5: Treino-Pré 3. TR7: Treino-Pré 4. J1: Pré-jogo 1. J2: Pré-jogo 2. J3: Pré-jogo 3. J4: Pré-jogo 4. TR2: Treino-Pós 1. TR4: Treino-Pós 2. TR6: Treino-Pós 3.

\section{Fator X-Descaso/Inveja}

Foi encontrada interação entre MOMENTO e EVENTO neste Fator da LEAP. Isto é, essas fontes de variação se interdependem, sendo que uma alteração em uma depende da outra ou então que há diferença no padrão de alteração delas conforme a mudança de outra.

Assim, encontrou-se diferença significativa no valor de presença de um EVENTO a outro dentro de um mesmo MOMENTO: Para o MOMENTO 1, encontrou-se diferença significativa entre os EVENTOS Treino-Pré (média 0,306; erro-padrão 0,029) e Pré-jogo (média 0,232; erro-padrão 0,029), sendo p=0,030; e entre os EVENTOS Treino-Pré (média 0,306; erro-padrão 0,029) e Treino-Pós (média 0,180; erro-padrão 0,024), sendo p=0,000. Não foi constatada diferença entre os EVENTOS nos MOMENTOS 2 e 3.

Sendo assim, no contexto do primeiro jogo, o valor de presença no Treino-Pré foi maior se comparado aos valores no Pré-jogo e no Treino-Pós. Nos contextos do segundo e terceiro jogos, os valores de presença nos EVENTOS não foram significativamente diferentes. 
Na comparação dos mesmos tipos de EVENTOS em diferentes MOMENTOS, encontrou-se diferença significativa no valor de presença, ou seja, dependendo do MOMENTO, o valor de presença para os tipos de EVENTO não é regular. Para o EVENTO 1, encontrou-se diferença entre os MOMENTOS 1 (média 0,306; erro-padrão 0,029) e 2 (média 0,209; erro-padrão 0,021), sendo p=0,000; e entre os MOMENTOS 1 (média 0,306; erro-padrão 0,029) e 3 (média 0,202; erro-padrão 0,037), sendo p=0,023. Não foi constatada diferença nos EVENTOS Pré-Jogo e Treino-Pós em nenhum MOMENTO.

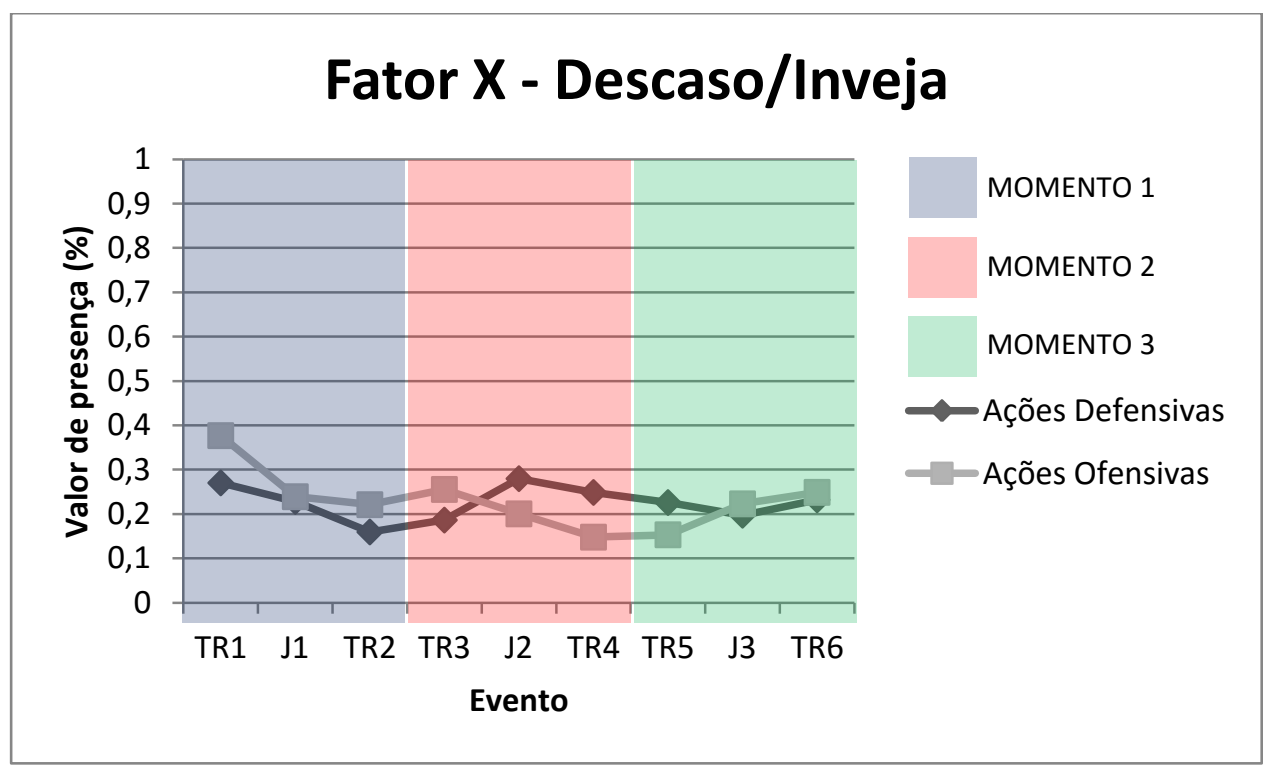

Figura 11. Médias dos grupos no Fator $X$ (Descaso/Inveja) da LEAP em cada evento. TR1: Treino-Pré 1. TR3: Treino-Pré 2. TR5: Treino-Pré 3. TR7: Treino-Pré 4. J1: Pré-jogo 1. J2: Pré-jogo 2. J3: Pré-jogo 3. J4: Pré-jogo 4. TR2: Treino-Pós 1. TR4: Treino-Pós 2. TR6: Treino-Pós 3.

Com isso, tem-se que o valor de presença no Treino-Pré no contexto do primeiro jogo foi maior se comparado aos valores de presença encontrados para esse EVENTO nos outros dois contextos (Figura 11). Os valores de presença no Pré-jogo e no Treino-Pós não foram significativamente diferentes nos diferentes contextos. 


\section{Fator XI-Receptividade}

Para o Fator XI, houve diferença significativa entre os MOMENTOS 1 (média 0,462; erro-padrão 0,033) e 2 (média 0,328; erro-padrão 0,034), sendo p=0,000; e entre os MOMENTOS 1 (média 0,462; erro-padrão 0,033) e 3 (média 0,350; erro-padrão 0,046), sendo $\mathrm{p}=0,004$. Também foi encontrada diferença significativa entre os EVENTOS TreinoPré (média 0,426; erro-padrão 0,039) e Pré-jogo (média 0,391; erro-padrão 0,035), sendo p=0,003; e Pré-jogo (média 0,391; erro-padrão 0,035) e Treino-Pós (média 0,323; erro-padrão 0,039), sendo $\mathrm{p}=0,008$.

Foi encontrada interação entre MOMENTO e EVENTO neste Fator da LEAP. Isto é, essas fontes de variação se interdependem, sendo que uma alteração em uma depende da outra ou então que há diferença no padrão de alteração delas conforme a mudança de outra.

Assim, encontrou-se diferença significativa no valor de presença de um EVENTO a outro dentro de um mesmo MOMENTO: Para o MOMENTO 1, encontrou-se diferença entre os EVENTOS Treino-Pré (média 0,538; erro-padrão 0,041) e Treino-Pós (média 0,355; erropadrão 0,039), sendo p=0,001; e entre os EVENTOS Pré-jogo (média 0,467; erro-padrão 0,033) e Treino-Pós (média 0,355; erro-padrão 0,039), sendo p=0,019. Para o MOMENTO 2, encontrou-se diferença entre os EVENTOS Treino-Pré (média 0,392; erro-padrão 0,034) e Treino-Pós (média 0,271; erro-padrão 0,041), sendo p=0,023. Para o MOMENTO 3 não foi encontrada diferença entre os EVENTOS.

Portanto, para ambos os grupos, no contexto do primeiro jogo, o valor de presença no Treino-Pós foi significativamente menor se comparado aos valores encontrados no Treino-Pré e no Pré-jogo. No contexto do segundo jogo, o valor de presença no Treino-Pós foi significativamente menor em comparação ao Treino-Pré. O valor no Pré-jogo foi maior que o Treino-Pós também, mas a diferença não foi estatisticamente significativa. No contexto do terceiro jogo, não foi encontrada diferença significativa nos valores dos EVENTOS. 


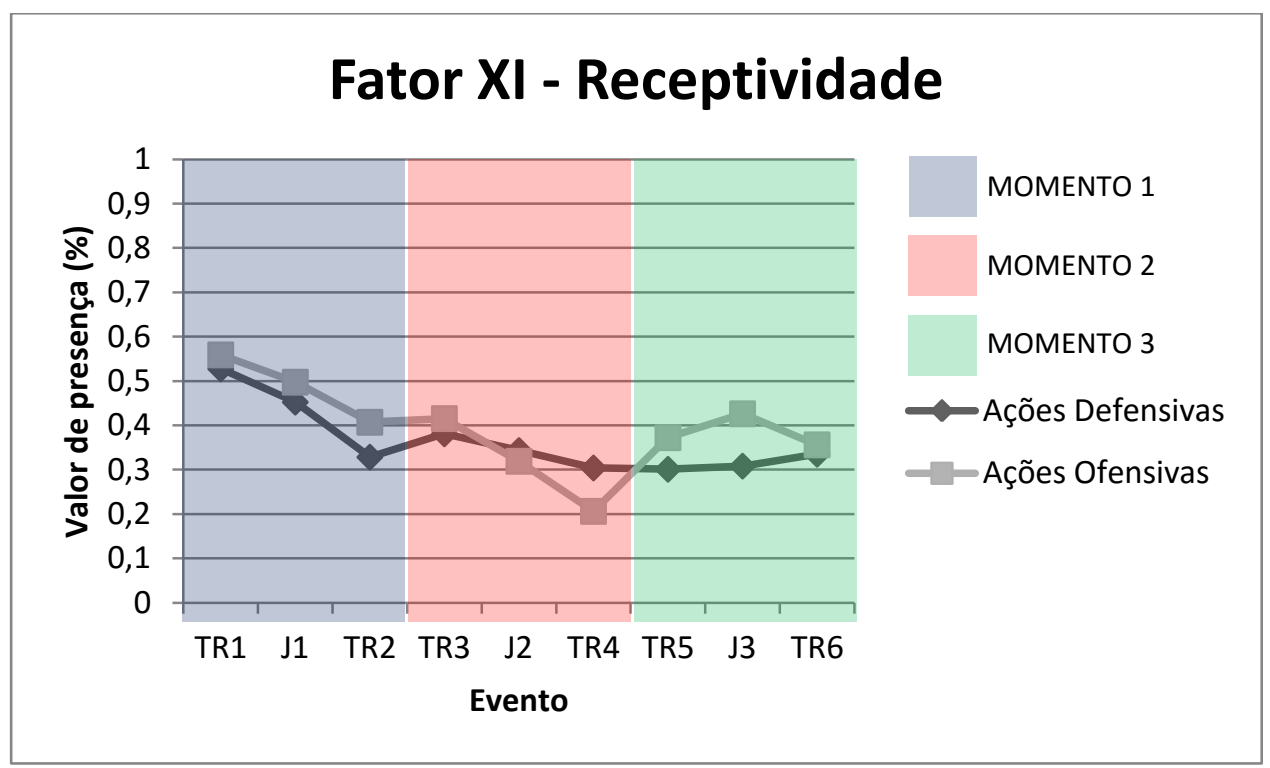

Figura 12. Médias dos grupos no Fator XI (Receptividade) da LEAP em cada evento. TR1: Treino-Pré 1. TR3: Treino-Pré 2. TR5: Treino-Pré 3. TR7: Treino-Pré 4. J1: Pré-jogo 1. J2: Pré-jogo 2. J3: Pré-jogo 3. J4: Pré-jogo 4. TR2: Treino-Pós 1. TR4: Treino-Pós 2. TR6: Treino-Pós 3.

Na comparação dos mesmos tipos de EVENTOS em diferentes MOMENTOS, encontrou-se diferença significativa no valor de presença, ou seja, dependendo do MOMENTO, o valor de presença para os tipos de EVENTO não é regular. Para o EVENTO Treino-Pré, encontrou-se diferença para os MOMENTOS 1 (média 0,538; erro-padrão 0,041) e 2 (média 0,392; erro-padrão 0,034), sendo p=0,001; e para os MOMENTOS 1 (média 0,538; erro-padrão 0,041) e 3 (média 0,325; erro-padrão 0,046), sendo p=0,000. Para o EVENTO Pré-Jogo, encontrou-se diferença para os MOMENTOS 1 (média 0,467; erro-padrão 0,033) e 2 (média 0,335; erro-padrão 0,041), sendo p=0,005; e para os MOMENTOS 1 (média 0,467; erro-padrão 0,033) e 3 (média 0,347; erro-padrão 0,043), sendo p=0,028. Não foi constatada diferença para o EVENTO Treino-Pós em nenhum MOMENTO.

Sendo assim, para ambos os grupos, o valor de presença deste Fator da LEAP no Treino-Pré foi maior no contexto do primeiro jogo se comparado ao valor nos outros dois contextos, os quais tiveram valores semelhantes (Figura 12). O valor de presença no Pré-jogo 
foi maior também no contexto do primeiro jogo se comparado ao valor nos outros dois contextos, os quais também tiveram valores semelhantes. O valor de presença no Treino-Pós não teve diferença significativa constatada.

\section{Fator XII - Serenidade}

Foi encontrada diferença significativa $(\mathrm{p}=0,023)$ entre os EVENTOS Treino-Pré (Média 0,387; erro-padrão 0,025) e Treino-Pós (média 0,321; erro-padrão 0,030), independentemente do MOMENTO e do GRUPO.

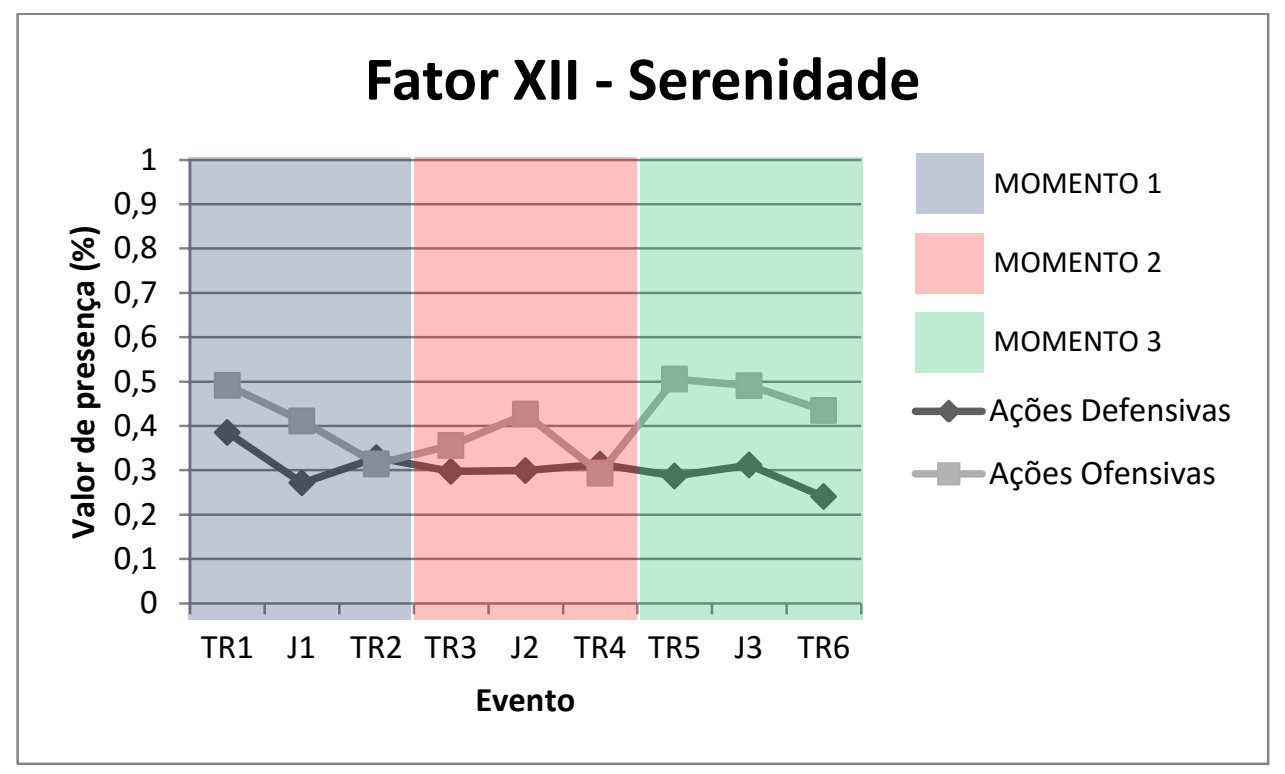

Figura 13. Médias dos grupos no Fator XII (Serenidade) da LEAP em cada evento. TR1: Treino-Pré 1. TR3: Treino-Pré 2. TR5: Treino-Pré 3. TR7: Treino-Pré 4. J1: Pré-jogo 1. J2: Pré-jogo 2. J3: Pré-jogo 3. J4: Pré-jogo 4. TR2: Treino-Pós 1. TR4: Treino-Pós 2. TR6: Treino-Pós 3.

Sendo assim, este Fator da LEAP cai entre o Treino-Pré e o Treino-Pós, independentemente do contexto e para ambos os grupos (Figura 13). $\mathrm{O}$ valor de presença no Pré-jogo obtido é intermediário a esses valores encontrados nos outros EVENTOS. 


\subsection{Análise das alterações dos estados de ânimo presentes em função do decurso temporal}

De acordo com os dados apresentados na seção anterior, nota-se que alguns Fatores da LEAP, mesmo considerados com nível de presença baixo durante o período estudado, apresentam padrões de alteração temporal, de um evento a outro, tendo o jogo como referência central desses padrões. Esse padrão de alteração em função do decurso temporal, ou seja, de um evento a outro, foi encontrado para os Fatores I (Humilhação/Raiva), II (Fadiga), VII (Interesse), IX (Fome) e XII (Serenidade). Como os Fatores I (Humilhação/Raiva) e IX (Fome) apresentaram níveis de presença baixos durante todo o período estudado, seus padrões não serão levados em conta nessa análise.

\subsection{Análise das alterações dos estados de ânimo presentes em função do intervalo temporal}

Ainda que se possa obter um padrão de alteração em função do decurso temporal, ou seja, de um evento a outro, percebeu-se que alguns Fatores da LEAP apresentaram variações em função de um intervalo temporal compreendido pelos eventos referentes ao mesmo jogo. Isto é, esta variação não se deu de um evento a outro, mas entre períodos delimitados de tempo que englobam Treino-Pré, Pré-Jogo e Treino-Pós. São os casos das alterações dos valores de presença Fatores IV (Limerência/Empatia) e VII (Interesse) em que ambos os Fatores tiveram suas médias de valor de presença maiores no período que abrange os eventos mais próximos ao primeiro jogo, tendo seu valor diminuído no período que abrange os eventos mais próximos ao segundo jogo. No período que abrange os eventos mais próximos ao terceiro jogo, suas médias de valor de presença foram maiores comparadas ao período do segundo jogo, mas menores se comparadas às médias do período do primeiro jogo, sem apresentar diferença estatisticamente significativa.

Vale ressaltar que o Fator II (Fadiga) apresentou uma alteração entre padrões temporais dependendo do GRUPO: o grupo de Ações Defensivas apresentou uma diferença 
nas médias de seu valor de presença do período do segundo jogo para o terceiro jogo, sendo a média do período do segundo jogo maior que a média do terceiro jogo.

\subsection{Análise das alterações dos estados de ânimo em função da interação entre decurso temporal e intervalo temporal}

Os Fatores III (Esperança), V (Fisiológico), VI (Repulsa), VIII (Surpresa), X (Descaso/Inveja) e XI (Receptividade) apresentaram um padrão de alteração que depende tanto do decurso temporal quanto do intervalo temporal. Como os Fatores VI (Repulsa), VIII (Surpresa) e X (Descaso/Inveja) apresentaram níveis de presença baixos durante todo o período estudado, seus padrões não serão levados em conta nessa análise.

Os Fatores III (Esperança) e XI (Receptividade) apresentaram um padrão de decaimento dos seus valores de presença entre o Treino-Pré e o Treino-Pós nos períodos do primeiro e segundo jogos. Isto é, o padrão de alteração destes fatores nesse período é semelhante ao padrão de alteração encontrado em todo o período do estudo para o Fator XII (Serenidade), em que os maiores valores de presença foram encontrados no ponto temporalmente mais distante entre os dois jogos nesses intervalos. No período do terceiro jogo, no entanto, o Fator III (Esperança) teve seu valor de presença aumentado entre o TreinoPré e o Pré-Jogo, enquanto que não foi encontrada diferença significativa entre os valores de presença do Fator XI (Receptividade) dos eventos no mesmo período.

Sobre o Fator V (Fisiológico), seu valor de presença aumentou do Pré-Jogo para o Treino-Pós no período do primeiro jogo; decréscimo do valor do Treino-Pré para o Pré-Jogo e aumento do valor do Pré-Jogo para o Treino-Pós no período do segundo jogo e; aumento do valor de presença tanto do Treino-Pré para o Pré-Jogo quanto do Pré-Jogo para o Treino-Pós no período do terceiro jogo. É o Fator da LEAP com o padrão de alteração mais dinâmico.

Tendo em vista as análises dos itens 5.4, 5.5 e 5.6, os padrões de alteração dos estados de ânimo deste estudo estão representados na Figura 14. 


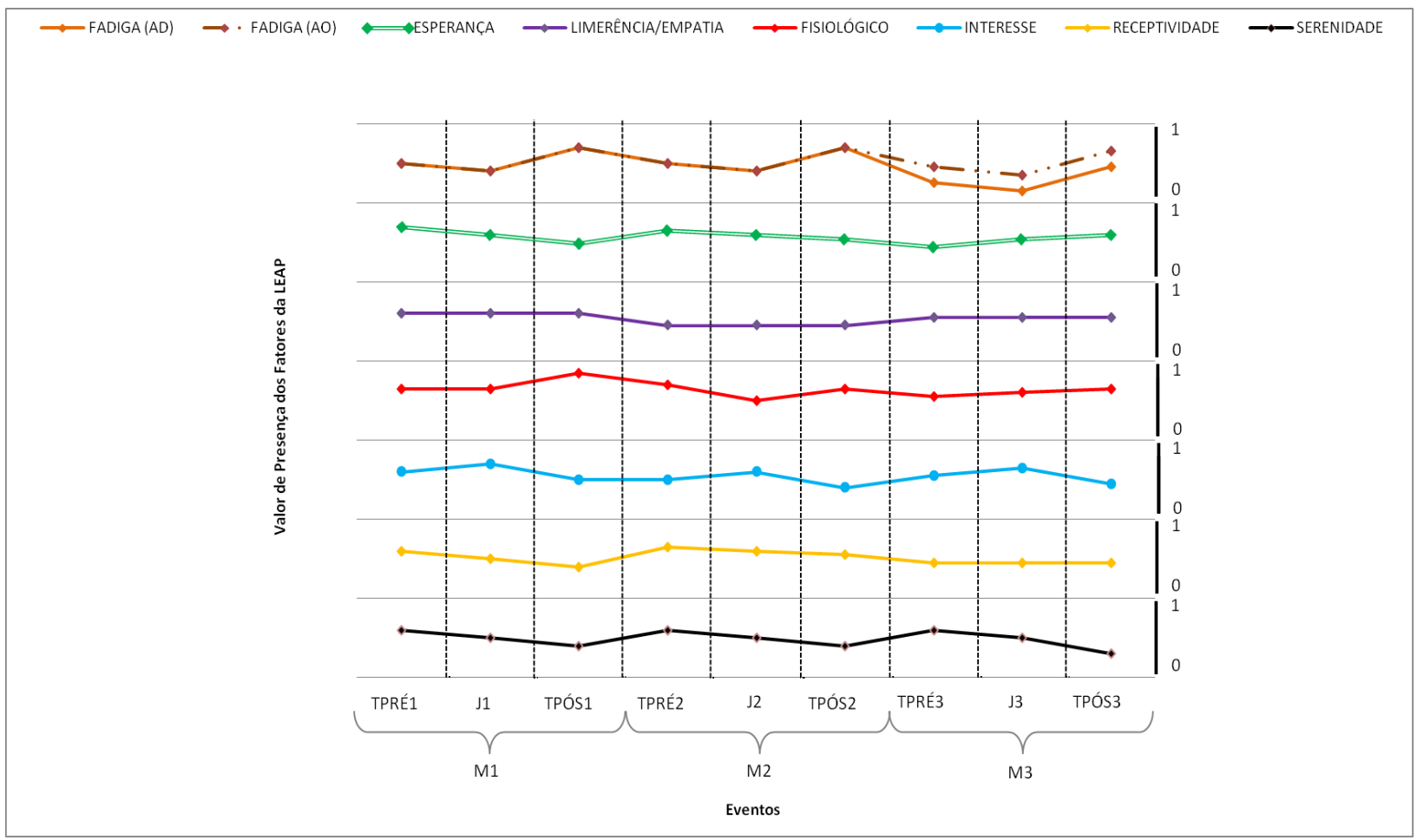

Figura 14. Padrões de alteração dos Fatores da LEAP representativos durante o período estudado.

\section{DISCUSSÃO}

Foram encontrados padrões de alteração dos estados de ânimo em função do decurso temporal entre um evento e outro, representados pelos Fatores II (Fadiga), VII (Interesse) e XII (Serenidade) da LEAP, sugerindo a presença dos processos de decaimento e expectativa desses estados de ânimo. Também foi encontrado que alguns estados de ânimo diferiram seus padrões de alteração de acordo com um intervalo temporal compreendido pelos eventos referentes ao mesmo jogo (Fatores IV - Limerência/Raiva e; VII - Interesse), bem como tiveram valores de presença diferentes na comparação entre esses intervalos. Além disso, os Fatores III (Esperança), V (Fisiológico) e XI (Receptividade) apresentaram padrões de alteração em função tanto do decurso temporal como dos intervalos temporais. 
Admitindo o critério estabelecido do jogo como marca central, os processos de decaimento dos estados de ânimo e expectativa podem ser analisados. O primeiro processo é definido como uma informação ou traço de memória que perde ativação ao longo do tempo (Brown, 1958; Ricker et al., 2014). O segundo processo é definido como a espera pela ocorrência de um evento em um determinado tempo (Boltz, 1993). Assim, tem-se que o decaimento refere-se a eventos que já ocorreram e a expectativa a eventos futuros.

Outros estudos mostram a relação dos estados de ânimo com o passar do tempo como o de De La Vega Marcos et al. (2008) em que os pesquisadores avaliaram os estados de ânimo pré-competitivos de jogadores de futebol durante a fase de play-off de um campeonato de nível nacional e não encontraram diferenças estatisticamente significativas nos índices dos Fatores do POMS (McNair et al., 1971; Morgan, 1980) comparando-se o início e o fim do período estudado, permanecendo o mesmo perfil anímico (“perfil iceberg”). Hassmén e Blomstrand (1995) avaliaram o perfil anímico de jogadoras de futebol também com o POMS em diferentes pontos do tempo (cerca de uma hora antes dos jogos, logo após os jogos e duas horas após os jogos) e encontraram diferenças do perfil anímico das atletas nesses diferentes pontos do tempo, relacionando essas diferenças com os resultados obtidos pela equipe nos jogos em que foram avaliadas. Keikha, Yusof e Jourkesh (2015) avaliaram com o POMS, em diferentes pontos do tempo (uma semana, um dia e uma hora antes das competições), os estados de ânimo de atletas universitários de gêneros diferentes e de várias modalidades, tanto individuais como coletivas, e verificaram que o perfil anímico dos participantes era diferente somente um dia antes das competições, se mantendo estável na comparação entre a avaliação de uma hora e uma semana antes das competições.

O presente estudo utilizou a LEAP (Engelmann, 1986) para o acesso aos estados de ânimo, pois é um instrumento confiável e capaz de avaliar um espectro grande de estados subjetivos não encontrados em outros instrumentos de língua portuguesa, adaptados ou 
desenvolvidos no Brasil. Os dados do presente trabalho apresentam regularidade com os dados obtidos com a LEAP em comparação aos achados de Bueno e Di Bonifácio (2007), Dias-Silva (2013), Di Bonifácio (2006, 2013), Nogueira (2009), Silva (2013) e Souza (2011, 2014) no momento pré-competitivo em que os Fatores III (Esperança) e VII (Interesse) compõem um perfil anímico comum de atletas de Futebol, Voleibol e Futsal na précompetição. Além disso, este estudo amplia a investigação dos estados de ânimo em atletas por avaliá-los não só no momento pré-competitivo, mas também antes de treinamentos, permitindo a análise das alterações desses estados de ânimo em função tanto do decurso temporal como de um intervalo temporal durante um período competitivo.

Diferentemente dos estudos prévios realizados com a LEAP (Bueno, De Martino \& Figueiredo, 2003; Bueno \& Di Bonifácio, 2007, 2009; De Martino \& Misko, 2004; Di Bonifácio, 2006, 2013; Dias-Silva, 2013; Nogueira, 2010; Silva, 2013; Souza, 2014, 2011), em que as relações dos estados de ânimo com outras variáveis eram descritas por meio das locuções do instrumento, pois suas variáveis se relacionavam diretamente com as locuções da LEAP, o presente estudo desenvolveu um método de análise quantitativa que pôde comparar os Fatores da LEAP propostos por Engelmann (1986) calculando seu valor de presença. Tal procedimento foi adotado com vistas a facilitar a análise dos processos anímicos ao longo do tempo já que os Fatores da LEAP representam os constructos que resumem os estados de ânimo observados. Esse avanço na forma de análise dos dados poderá guiar ou auxiliar novas investigações sobre estados de ânimo com esse instrumento.

Apesar de não atingir o critério de nível de presença adotado neste estudo, o Fator I (Humilhação/Raiva) mostrou o mesmo padrão de alteração que o Fator II (Fadiga). Esses dados mostram uma regularidade também encontrada nos estudos de Bueno e Di Bonifácio (2007), Dias-Silva (2013), Di Bonifácio (2006, 2013), Souza (2011, 2014) e Silva (2013), em que a locução "Estou alegre" é presente antes dos jogos e, por ser a única locução 
correlacionada negativamente com o Fator I (Humilhação/Raiva), o valor de presença do Fator diminui. Por terem sido derrotados em todos os jogos no período do estudo, o resultado da partida pode ter afetado os estados de ânimo presentes dos jogadores, conforme o ocorrido no estudo de Nogueira (2009), em que os estados de ânimo presentes após as derrotas com maior intensidade foram locuções com correlação alta com o Fator I (Humilhação/Raiva) que aumentavam sua intensidade após a derrota, fazendo com que seu valor de presença aumentasse. No presente estudo, mesmo com o aumento do valor de presença desse Fator após as derrotas, o critério de presença do Fator para análise quantitativa não foi atingido.

Conforme também observado nos estudos de Bueno e Di Bonifácio (2007), Dias-Silva (2013), Di Bonifácio (2006, 2013), Nogueira (2009), Silva (2013) e Souza (2011, 2014), o Fator XI (Repulsa) teve um nível de presença baixo durante todo o período estudado, não podendo ser observado um padrão de alteração desse Fator neste estudo. Conclui-se que este Fator pode não ser relevante ou representativo no contexto esportivo visto sua ausência nos diferentes estudos supracitados. Em contrapartida, o Fator XI (Repulsa) parece ser muito relevante no contexto hospitalar, segundo o que os dados de Bueno, De Martino e Figueiredo (2003) sugerem.

Diferentemente do que foi encontrado nos estudos de Dias-Silva (2013), Nogueira (2009) e Silva (2013), foram poucas as diferenças em função da posição dos jogadores. O grupo de Ações Defensivas apresentou média decrescente do valor de presença do Fator II (Fadiga) nos intervalos temporais do segundo e do terceiro jogos. O grupo de Ações Ofensivas apresentou uma média decrescente no valor de presença do Fator VIII (Surpresa) ao longo do período estudado, do primeiro ao último evento. O fato de terem sido encontradas poucas diferenças em função da posição dos jogadores para a maioria dos Fatores da LEAP pode ter relação com a forma de agrupamento utilizada para a constituição dos grupos de Ações Defensivas e Ações Ofensivas. 


\subsection{Alterações dos estados de ânimo presentes em função do decurso temporal}

A presença do Fator VII (Interesse) se alterou em contraponto à alteração da presença do Fator II (Fadiga) durante o período estudado. Enquanto o Fator VII (Interesse) teve seu valor de presença incrementado com a proximidade do jogo, a presença do Fator II (Fadiga) diminuiu concomitantemente.

O estudo de Torres-Luque et al. (2013), que avaliou com POMS_a relação dos estados de ânimo com as cargas de treinamento durante um período competitivo em judocas, mostra que antes da competição o Fator Fadiga do POMS também diminui de valor, ao passo que aumenta após a competição. Nogueira (2009) mostra que futebolistas de equipes sub-15 e sub-17 apresentam alta intensidade no índice de presença na locução "Estou cansado", que é a locução com a maior carga no Fator II (Fadiga), logo após os jogos, independentemente do resultado da partida. Apesar de a avaliação no presente estudo ter sido feita 48 horas após os jogos, o padrão de alteração dos estados de ânimo permanece. O Fator Fadiga do POMS aparece com seu valor aumentado após as competições de diversas modalidades em diversos estudos (Ahmadi, Far, \& Kazemzadeh, 2015; De La Vega Marcos et al., 2008; Hassmén \& Blomstrand, 1995; Umeda et al., 2008). É esperado que, após esforço físico e mental, a fadiga tenha seu nível aumentado.

O Fator VII (Interesse) parece ser um Fator presente na iminência do jogo, como mostram os estudos de Bueno e Di Bonifácio (2007), Dias-Silva (2013), Di Bonifácio (2006, 2013), Silva (2013) e Souza $(2011,2014)$. Esse fator está ligado a uma expectativa pela ocorrência de algum evento, o que dá suporte à inclusão da análise da influência desse processo no presente estudo. Além disso, pode-se considerar que este Fator está também relacionado à ativação orgânica e à motivação. Pujals e Vieira (2002) encontraram em seu estudo que um interesse específico (melhorar o próprio desempenho) é um fator psicológico positivo presente em atletas juvenis de futebol que interfere no desempenho em campo. 
Melhorar o próprio desempenho é um fator motivacional ligado à necessidade de realização (Elliot \& Dweck, 2005; Elliot, Murayama, \& Pekrun, 2011; Mascret, Elliot, \& Cury, 2015). Interesse também pode estar ligado à motivação intrínseca, que Ryan e Deci (2000) postulam como uma tendência natural e inerente para buscar novidades e desafios, bem como para obter e exercitar as capacidades; pode estar, ainda, ligado à motivação extrínseca, que se refere a fazer algo que leve a algum resultado com ganho externo. Além disso, sobre a relação com a ativação orgânica, outros estudos mostram que o Fator Tensão do POMS ou estados de prontidão (LEAP) aumentam de intensidade, isto é, suas presenças nos dias de competição (Di Bonifácio, 2013; Dias-Silva, 2013; Hassmén \& Blomstrand, 1995; Keikha et al., 2015; Torres-Luque et al., 2013).

\subsection{Alterações dos estados de ânimo presentes em função do intervalo temporal}

Os Fatores IV (Limerência/Empatia) e VII (Interesse) apresentaram médias de valor de presença diferentes dependendo do período temporal, sem apresentar diferenças entre os grupos nem entre os eventos ao longo desses períodos. Nota-se que as médias dos valores de presença desses Fatores da LEAP decresceram assim que as chances de classificação da equipe para a próxima fase do campeonato também ficaram remotas. A relação entre esses Fatores da LEAP nesse contexto parece se dar na interação entre coesão grupal, que é um processo dinâmico refletido na tendência de um grupo para confiança e unidade na busca de suas metas e objetivos (Carron, Widmeyer, \& Brawley, 1985), e motivação, especialmente às metas de realização (Mascret et al., 2015; Pekrun, Elliot, \& Maier, 2006; Pintrich, 2000). Como já mencionado, a equipe não conseguiu se classificar à próxima fase (play-off). No período entre o primeiro e segundo jogos desse estudo, as chances de classificação ficaram muito remotas, sendo que após o segundo jogo a equipe já estava eliminada da competição, participando dos jogos restantes para "cumprir tabela". Isso pode ter afetado a coesão de grupo justificando o decréscimo de valor do Fator IV (Limerência/Empatia). Estudos futuros 
poderão dar conta de uma análise mais criteriosa da relação entre coesão de grupo ou outros processos coletivos e aspectos emocionais, bem como a relação entre esses aspectos emocionais e aspectos motivacionais.

Ainda que tenham diminuído seus valores de presença, na média, entre esses intervalos de tempo, ambos os Fatores continuaram com nível de presença médio, segundo o critério adotado neste estudo. Assim, esses dados sugerem que, independentemente desse contexto não favorável, os estados de ânimo relacionados a esses Fatores da LEAP são comuns à experiência esportiva competitiva coletiva de alto rendimento.

\subsection{Alterações dos estados de ânimo presentes em função da interação entre decurso temporal e intervalo temporal}

Durante os períodos temporais do primeiro e segundo jogos, os Fatores III (Esperança) e XI (Receptividade) apresentaram alterações similares, decaindo o valor entre o Treino-Pré e o Treino-Pós. O Fator V (Fisiológico) apresentou um padrão bem dinâmico de alteração, pois mostrou em cada intervalo temporal um padrão de alteração em função do decurso temporal distinto.

Nota-se que a média do valor de presença do Fator III (Esperança) ficou menor assim que a possibilidade de serem desclassificados aumentou ou que a desclassificação já estava definida. Ainda assim, este Fator é presente em todos os eventos do período estudado. Di Bonifácio (2013) mostra que este Fator da LEAP foi presente nas fases iniciais de uma competição de nível internacional em jogadoras de voleibol de alto rendimento, não permanecendo com intensidade alta no desenrolar da competição. Pujals e Vieira (2002) encontraram também a esperança como fator psicológico positivo em atletas juvenis de futebol que influencia o desempenho em campo.

Nos estudos de Nogueira (2009) e Silva (2013), os meio-campistas da equipe sub-15 e da equipe sub-17 apresentaram alta intensidade das locuções com as maiores cargas de 
correlação com o Fator XI (Receptividade) após os jogos em que foram derrotados. No presente estudo, não foi notada diferença entre os grupos para este Fator da LEAP. Contudo, este Fator mostrou-se presente após as derrotas, apesar de seu valor de presença ter diminuído em comparação aos valores na pré-competição.

A locução "Estou com frio", com carga negativa no Fator V (Fisiológico), aumentou antes dos jogos, fazendo com que o valor de presença do Fator diminuísse, principalmente no segundo jogo do estudo, o qual era determinante às chances de classificação para a próxima fase. Esses dados não corroboram com os achados de Di Bonifácio (2013), em que a locução "Estou com sede" aparece com maior intensidade nos jogos decisivos de uma competição de voleibol. No entanto, sentir frio é um dos relatos comuns à sensação de ansiedade em geral (Andrade \& Gorestein, 2000). Hernandez e Gomes (2002) encontraram uma relação inversa entre ansiedade pré-competitiva e coesão de grupo em torno da tarefa, o que vai ao encontro dos dados do presente estudo, considerando os achados acerca do Fator IV (Limerência/Empatia). No entanto, ansiedade pré-competitiva pode não ser um fator psicológico relevante para uma população de atletas jovens (Interdonato, Oliveira, Junior, \& Greguol, 2010)

Apesar de não terem sido objeto de estudo do presente trabalho, constatou-se que alguns elementos como chance de classificação e resultado das partidas (particularmente a derrota) influenciaram a forma como os estados de ânimo se alteraram durante o período estudado. Esta afirmação se dá com base na literatura em que a derrota elicia emoções negativas e causa diminuição das emoções positivas nos atletas após a competição (Ahmadi et al., 2015; Hassmén \& Blomstrand, 1995; Marc V. Jones \& Sheffield, 2007; Nogueira, 2009; Rubio, 2006) e que estados de ânimo mudam sua intensidade conforme o avanço na competição (Bueno \& Di Bonifácio, 2007). Rubio (2006) comenta que a derrota causa no derrotado vergonha pelo objetivo perdido, falta de reconhecimento pelo esforço realizado 
(motivação extrínseca) e frustração por não conseguir lidar com uma expectativa não realizada. Estas afirmações mostram componentes emocionais (vergonha, frustração, tristeza) e motivacionais (objetivos, falta de reconhecimento) que os dados do presente estudo corroboram.

Sobre a dinamicidade dos estados de ânimo, isto é, suas mudanças ao longo do tempo, os dados deste estudo permitem dizer que o processo de decaimento e a expectativa estão relacionados às alterações. Outras variáveis poderão influência sobre a presença ou não dos estados de ânimo. No entanto, ignorar o decurso temporal como fator influente nas mudanças dos estados de ânimo fará com que qualquer enunciado sobre o assunto fique incompleto (Ricker et al., 2014). Tanto o processo de decaimento como a expectativa como fatores influentes às alterações mostram a relevância da temporalidade nas alterações aqui estudadas. Processos que englobam a antecipação de algum evento geram uma ativação do organismo a uma situação presente que, se for ameaçadora, pode ser entendida como ansiedade - o que justifica os muitos trabalhos sobre esse tema no esporte no início das investigações nesse contexto; se for uma espera positiva passiva, pode ser entendida como esperança; se for uma espera positiva ativa, pode ser entendida como interesse - dois dos estados de ânimo inclusos na LEAP.

O presente estudo permite a elaboração de um modelo psicobiológico de alteração dos estados de ânimo aplicados ao esporte, apesar de os resultados serem referentes a uma fase específica de um campeonato, com uma amostra composta por atletas de alto rendimento juvenis e os jogos terem terminado sempre em derrota da equipe. É preciso assumir que um dos componentes básicos para o avanço do estudo da psicobiologia do comportamento é o reconhecimento de processos dinâmicos, que levem em conta a passagem do tempo (Staddon \& Bueno, 1991). Pesquisas futuras poderão expandir a análise com dados complementares e aprimorar o modelo possível com os dados do presente estudo. 


\section{CONCLUSÃO}

Os estados de ânimo de jovens atletas de futebol se alteram ao longo do tempo, em padrões específicos, considerando a ação do decaimento e da expectativa dentro de um contexto esportivo. Variáveis contextuais como o resultado das partidas e a competição esportiva em si também foram influentes nessas alterações. Fadiga, esperança, empatia, estados ligados à propriocepção, interesse, receptividade e serenidade foram os estados de ânimo presentes durante todo o estudo.

Ressalta-se a importância de incluir a temporalidade como variável influente nos modelos de variação de processos neurobiológicos, sobretudo nas investigações acerca de aspectos subjetivos como os estados de ânimo. O contexto esportivo mostra-se um campo de estudos adequado para o desenvolvimento de modelos neurobiológicos dinâmicos do comportamento por possibilitar, dentro de sua peculiaridade, relações entre variáveis contextuais (competição, treinamento, regras de jogo, resultados da partida etc.), aspectos fisiológicos (hormônios, freqüência cardíaca, fMRI, Eletroencefalograma etc.), aspectos psicológicos (motivação, estados subjetivos, cognição, atenção, memória etc.), aspectos sociais (coesão de grupo, relações hierárquicas, relação com adversários, práticas culturais etc.) e o tempo. 


\section{REFERÊNCIAS BIBLIOGRÁFICAS}

Abenza, L., Olmedilla, A., Ortega, E., Ato, M., \& García-Mas, A. (2010). Análisis de la relación entre el estado de ánimo y las conductas de adherencia en deportistas lesionados. [Analysis of the relationship between mood states and adherence behavior in injured athletes.]. Anales de Psicología, 26(1), 159-168.

Ahmadi, E., Far, A. B., \& Kazemzadeh, Y. (2015). Studying of Winning or Losing on the Quality of Mood and Salivary Cortisol Concentrations in Female Futsalists, 7(2), 9-12.

Andrade, L., \& Gorestein, C. (2000). Aspectos gerais das escalas de avaliação de ansiedade.

In C. Gorenstein \& E. Al. (Eds.), Escalas de avaliação clínica em psiquiatria e psicofarmacologia (pp. 139-144). São Paulo: Lemos Editorial.

Arruza, J., Balagué, G., \& Arrieta, M. (1998). Rendimiento deportivo e influencia Del estado de ánimo, de la dificultad percibida y de la autoeficacia em el deporte de alta competición. Revista de Psicologia Del Deporte, 7(2), 193-204.

Boltz, M. G. (1993). The generation of temporal and melodic expectancies during musical listening. Perception \& Psychophysics, 53(6), 585-600.

http://doi.org/10.3758/BF03211736

Bray, S. R., \& Martin, K. a. (2003). The effect of competition location on individual athlete performance and psychological states. Psychology of Sport and Exercise, 4(2), 117-123. http://doi.org/10.1016/S1469-0292(01)00032-2

Brown, J. (1958). Some tests of the decay theory of immediate memory. Quarterly Journal of Experimental Psychology, 10(1), 12-21. http://doi.org/10.1080/17470215808416249

Bueno, J. L. O., De Martino, M. M. F., \& Figueiredo, T. H. (2003). Present Mood States in Brazilian Night Nurses. Psychological Reports, 93(2), 353-357. http://doi.org/10.2466/pr0.2003.93.2.353

Bueno, J. L. O., \& Di Bonifácio, M. A. (2007). Alterações de estados de ânimo presentes em atletas de voleibol, avaliados em fases do campeonato. Psicologia Em Estudo, 12(1), 179-184.

Bueno, J. L. O., \& Di Bonifácio, M. A. (2009). Variações emocionais e desempenho de atetas. In S. R. Pasian, G. Romanelle, \& M. V. Da Cunha (Eds.), Investigação científica em Psicologia: Aplicações atuais em saúde. São Paulo: Vetor Editora Psico-pedagógica.

Carron, A. V., Widmeyer, W. N., \& Brawley, L. R. (1985). The Development of an Instrument to Assess Cohesion in Sport Teams - The Group Enviroment Questionnaire. 
Journal of Sport Psychology, 7(3), 244-266.

Cerin, E., Szabo, A., Hunt, N., \& Williams, C. (2000). Temporal patterning of competitive emotions: A critical review. Journal of Sports Sciences, 18(8), 605-626. http://doi.org/10.1080/02640410050082314

Da Silva, M. M. F., Vidual, M. B. de P., Afonso, R. O., Yoshida, H. M., Borin, J. P., \& Fernandes, P. T. (2014). Ansiedade e desempenho de jogadoras de voleibol em partidas realizadas dentro e fora de casa. Revista Da Educação Física/UEM, 25(4), 585. http://doi.org/10.4025/reveducfis.v25i4.24347

De La Vega Marcos, R., Barquín, R. R., Alexandre, G. M., Balagué, G., Zafra, A. O., \& Del Valle Díaz, S. (2008). Consistencia y fluctuación de los estados de ánimo en un equipo de fútbol profesional durante una competición de play off. Revista de Psicologia Del Deporte, 17(2), 241-251.

De Martino, M. M. F., \& Misko, M. D. (2004). Estados emocionais de enfermeiros no desempenho profissional em unidades críticas. Revista Da Escola de Enfermagem USP, $38(2), 161-167$.

De Rose Junior, D. (1998). Lista de sintomas de stress pré-competitivo infanto-juvenil: elaboração e validação de um instrumento. Revista Paulista de Educação Física, 12(1977), 126-133.

De Rose Junior, D., Korsakas, P., \& Deschamps, S. R. (1999). Situações causadoras de stress no basquetebol de alto rendimento: fatores competitivos. Revista Paulista de Educação Física, 13(2), 217-229.

Di Bonifácio, M. A. (2006). Variações de estados de ânimo momentâneos do levantador e atacante, em jogos de voleibol. (Dissertação de mestrado não publicada). Faculdade de Filosofia, Ciências e Letras de Ribeirão Preto. Ribeirão Preto, São Paulo.

Di Bonifácio, M. A. (2013). Os estados de ânimo pré-competitivos e o desempenho de atletas de voleibol de alto nível. (Tese de doutorado não publicada). Faculdade de Filosofia, Ciências e Letras de Ribeirão Preto. Ribeirão Preto, São Paulo.

Dias, C., Corte-Real, N., Cruz, J. F. A., \& Fonseca, A. M. (2013). Emoções no desporto: O que sabemos e o (que sentimos) que julgamos saber. Revista de Psicología Del Deporte, 22(2), 473-480. Retrieved from http://www.redalyc.org/pdf/2351/235128058016.pdf

Dias-Silva, W. (2013). Relação entre estados de ânimo momentâneo e desempenho em atletas de futebol de campo. (Dissertação de mestrado). Faculdade de Filosofia, Ciências e Letras de Ribeirão Preto. Ribeirão Preto, São Paulo. Retrieved from http://www.teses.usp.br/teses/disponiveis/59/59134/tde-21112013-110917/pt-br.php 
Elliot, A. J., \& Dweck, C. S. (2005). Handbook of Competence and Motivation (Vol. 1). New York: Guilford Press.

Elliot, A. J., Murayama, K., \& Pekrun, R. (2011). A $3 \times 2$ achievement goal model. Journal of Educational Psychology, 103(3), 632-648. http://doi.org/10.1037/a0023952

Engelmann, A. (1978). Os Estados Subjetivos: Uma Tentativa de Classificação de seus Relatos Verbais. São Paulo: Ática.

Engelmann, A. (1986). Lep - uma lista, de origem brasileira, para medir a presença de estados de ânimo no momento em que está sendo respondida. Ciência E Cultura, 38(1), 121146.

Engelmann, A. (2002). Da Conceituação de Estado Subjetivo até a Proposição dos Escalões de Percepto. Psicologia: Reflexão E Crítica, 15(2), 393-405.

Figueiredo Filho, D. B., \& Silva Júnior, J. A. Da. (2010). Visão além do alcance: uma introdução à análise fatorial. Opinião Pública, 16(1), 160-185. http://doi.org/10.1590/S0104-62762010000100007

Frazier, E. (1988). Mood state profiles of chronic exercisers with differing abilities. International Journal of Sport Psychology, 19, 65-71.

Friend, J., \& LeUnes, A. D. (1990). Predicting baseball player performance. Journal of Sport Behavior, 13, 73-86.

Hanin, Y. L. (1997). Emotions and Athletic performance: Individual zones of optimal functioning model. European Yearbook of Sport Psychology, 1, 29-72.

Hassmén, P., \& Blomstrand, E. (1995). Mood State Relationships and Soccer Team Performance. The Sport Psychologist, 9, 297-308.

Hernandez, J. A. E., \& Gomes, M. D. M. (2002). Coesão grupal, ansiedade pré-competitiva e o resultado dos jogos em equipes de futsal. Revista Brasileira de Ciências Do Esporte, 24(1), 139-150. Retrieved from https://www.rbceonline.org.br/revista/index.php?journal=RBCE\&page=article \&op=dow nload\&path[\%

Hoffmann, J. R., Bar-Eli, M., \& Tenenbaum, G. (1999). An Examination of mood changes and performance in a professional basketball team. Journal of Sports Medicine and Physical Fitness, 39, 74-79.

Interdonato, G. C., Oliveira, A. R. De, Junior, C. C. L., \& Greguol, M. (2010). Analysis of competitive trait anxiety in young. Revista Da Faculdade de Educação Física Da UNICAMP, 8(3), 1-9.

Jones, M. V., \& Sheffield, D. (2007). The impact of game outcome on the well-being of 
athletes. International Journal of Sport and Exercise Psychology, 5(1), 54-65. http://doi.org/10.1080/1612197X.2008.9671812

Jones, M. V, Mace, R. D., \& Williams, S. (2000). Relationship between emotional state and performance during international field hockey matches. Perceptual and Motor Skills, 90(2), 691-701. http://doi.org/10.2466/PMS.90.2.691-701

Keikha, B. M., Yusof, S., \& Jourkesh, M. (2015). The Relationship between Pre-Competition State Anxiety Components and Mood State Sub-Scales Scores and the Result of among College Athletes through Temporal Patterning. International Journal of Sports Science, 5(1), 8-15. http://doi.org/10.5923/j.sports.20150501.02

Kerr, J. H., \& Schaik, P. Van. (1995). Effects of game venue and outcome on psychological mood states in rugby Notes and Shorter Communications. Personality and Individual Differences, 19, 407-410.

Martens, R., Vealey, R. S., \& Burton, D. (1990). Competitive anxiety in sport. Champaign, IL: Human Kinectics Inc.

Mascret, N., Elliot, A. J., \& Cury, F. (2015). Extending the $3 \times 2$ achievement goal model to the sport domain: The $3 \times 2$ Achievement Goal Questionnaire for Sport. Psychology of Sport and Exercise, 17, 7-14. http://doi.org/10.1016/j.psychsport.2014.11.001

McGowan, R. W., \& Miller, M. J. (1989). Differences in mood states between succesful and less successful karate participants. Perceptual and Motor Skills, 68(2), 505-506. http://doi.org/10.2466/pms.1989.68.2.505

McNair, D. M., Lorr, M., \& Droppelman, L. F. (1971). Manual for the Profile of Mood States. San Diego, CA: Educational and Industrial Testing Services.

Morgan, W. P. (1980). Test of the champions: the iceberg profile. Psychology Today, 6(July), $92-108$.

Morgan, W. P., Costill, D. L., Flynn, M. G., Raglin, J. S., \& O’Connor, P. J. (1988). Mood disturbance following increased training in swimmers. Medicine and Science in Sports and Exercise, 20(4), 408-414.

Noce, F., \& Samulski, D. M. (2002a). Análise do Estresse Psíquico em Atacantes no voleibol de alto nível. Revista Paulista de Educação Física, 16(2), 113-129.

Noce, F., \& Samulski, D. M. (2002b). Análisis Del Estrés Psíquico en Colocadores Brasileños de Voleibol de alto nivel. Revista de Psicología Del Deporte, 11(1), 137-155.

Nogueira, J. E. (2009). Alterações de estados de ânimo em atletas de futebol de campo, avaliados em fase do campeonato. Trabalho de Conclusão de Curso. Centro Universitário Moura Lacerda/Faculdade de Filosofia, Ciências e Letras de Ribeirão 
Preto. Universidade de São Paulo, Ribeirão Preto/SP.

Nowlis, V. (1965). Research with the mood adjective checklist. In S. S. Tomkins \& C. E. Izard (Eds.), Affect, cognition and personality. New York: Springer.

Pekrun, R., Elliot, A. J., \& Maier, M. A. (2006). Achievement goals and discrete achievement emotions: A theoretical model and prospective test. Journal of Educational Psychology, 98(3), 583-597. http://doi.org/10.1037/0022-0663.98.3.583

Pintrich, P. R. (2000). An Achievement Goal Theory Perspective on Issues in Motivation Terminology, Theory, and Research. Contemporary Educational Psychology, 25(1), 92104. http://doi.org/10.1006/ceps.1999.1017

Pujals, C., \& Vieira, L. F. (2002). Análise dos Fatores Psicológicos que interferem no comportamento dos atletas de futebol de campo. Revista Da Educação Física/UEM, 13(1), 89-97.

Ricker, T. J., Vergauwe, E., \& Cowan, N. (2014). Decay theory of immediate memory: From Brown (1958) to today (2014). Quarterly Journal of Experimental Psychology (2006), (May), 1-27. http://doi.org/10.1080/17470218.2014.914546

Rowley, A. J., Landers, D. M., Kyllo, L. B., \& Etnier, J. L. (1995). Does the Iceberg Profiie Discriminate Between Successfui and Less Successfui Atiiietes? A Meta-Anaiysis. Journal of Sport \& Exercise Psychology, 17, 185-199.

Rubio, K. (2006). O imaginário da derrota no esporte contemporâneo. Psicologia \& Sociedade, 18(1), 86-91.

Ryan, R. M., \& Deci, E. L. (2000). Intrinsic and Extrinsic Motivations: Classic Definitions and New Directions. Contemporary Educational Psychology, 25(1), 54-67. http://doi.org/10.1006/ceps.1999.1020

Samulski, D. (1992). Psicologia do Esporte: teoria e aplicação prática. Belo Horizonte: Imprensa Universitária/UFMG.

Silva, R. C. da. (2013). Relação entre estados de â nimo momentâneos e desempenho dentro e fora de casa em atletas de futebol. (Trabalho de Conclusão de Curso não publicado). Faculdade de Filosofia, Ciências e Letras de Ribeirão Preto. Ribeirão Preto, São Paulo.

Smith, R. E., Smoll, F. L., \& Schultz, R. W. (1990). Measurement and correlates os sportspecific cognitive and somatic trait anxiety: The Sport Anxiety Scale. Anxiety Research, 2, 263-280.

Souza, V. C. (2011). Variações de estados de ânimo momentâneos de jogadres de futsal em função da posicção, em situação pré-competitiva. (Trabalho de Conclusão de Curso). Faculdade de Filosofia, Ciências e Letras de Ribeirão Preto. Ribeirão Preto, São Paulo. 
Souza, V. C. (2014). Relações entre estados de ânimo pré-competitivos e desempenho de atletas de alto rendimento em jogos de futsal. (Dissertação de mestrado). Faculdade de Filosofia, Ciências e Letras de Ribeirão Preto. Ribeirão Preto, São Paulo. Retrieved from http://www.teses.usp.br/teses/disponiveis/59/59134/tde-05012015-164916/pt-br.php

Spielberger, C. D. (1983). Manual for the State-Trait Anxiety Inventory (Form Y). Palo Alto, CA: Mind Garden.

Spielberger, C. D. (1989). State-Trait Anxiety Inventory: A comprehensive bibliography. Palo Alto, CA: Consulting Psychologists Press.

Staddon, J. E., \& Bueno, J. L. O. (1991). On models, Behaviorism and the Neural basis of Learning. Psychological Science, 2(1), 3-11.

Torres-Luque, G., Hernández-García, R., Olmedilla, A., Toro, E. O., \& Vallejo, N. G. (2013). Fluctuación del perfil de estados de Ánimo (POMS) en un periodo competitivo en judokas de élite. Revista de Psicologia Del Deporte, 22(2), 313-320.

Umeda, T., Suzukawa, K., Takahashi, I., Yamamoto, Y., Tanabe, M., Kojima, A., ... Sugawara, N. (2008). Effects of intense exercise on the physiological and mental condition of female university judoists during a training camp. Journal of Sports Sciences, 26(9), 897-904. http://doi.org/10.1080/02640410801885917

Vieira, L. F., Nascimento Júnior, J. R. A., \& Vieira, J. L. L. (2013). O estado da arte da pesquisa em Psicologia do Esporte no Brasil. Revista de Psicología Del Deporte, 22(2), 501-507. Retrieved from http://ddd.uab.cat/pub/revpsidep/revpsidep_a2013v22n2/revpsidep_a2013v22n2p501.pdf 


\section{UNIVERSIDADE DE SÃO PAULO \\ Faculdade de Filosofia, Ciências e Letras de Ribeirão Preto \\ Departamento de Psicobiologia}

\section{TERMO DE ASSENTIMENTO}

Você está sendo convidado a participar de uma pesquisa pertencente ao projeto intitulado “Alterações dos estados de ânimo pré-evento em jovens atletas de futebol”, cujo objetivo é avaliar as alterações dos estados emocionais presentes do jogador de futebol de campo durante o decorrer de um período competitivo.

Num evento de jogo, antes da preleção, no vestiário, você receberá uma lista com quarenta frases escritas na primeira pessoa do singular, as quais nomeiam os estados emocionais. Num evento de treinamento, você receberá a mesma lista antes de entrar no campo de treinamento em local reservado no mesmo espaço do treinamento. Este instrumento torna possível medir a presença de emoções do indivíduo no instante em ele que está respondendo a lista de frases.

Espera-se com esta pesquisa entender melhor e verificar como o estado emocional do atleta é alterado no decorrer de um período de competição em função da enormidade de variáveis que existem no contexto esportivo e, a partir disso, possibilitar à comissões técnicas de clubes de futebol ter mais subsídios para trabalhar na melhoria do desempenho e bem-estar dos jogadores.

A sua participação na pesquisa não é obrigatória. Caso você concorde em prosseguir como voluntário, saiba que é livre para interromper a sua participação a qualquer momento e, se assim o fizer, não haverá prejuízos de qualquer ordem em função desta decisão.

$\mathrm{O}$ experimento ao qual você será submetido não apresenta riscos previsíveis à sua saúde física ou mental, não envolvendo qualquer droga ou medicamento, nem procedimentos invasivos.

Após a sua participação, é garantido a você o recebimento de esclarecimentos atualizados sobre qualquer etapa deste trabalho. As informações obtidas serão utilizadas para trabalhos científicos, porém a sua identificação será mantida sob sigilo, isto é, não haverá chance de ser identificado o seu nome e imagem, assegurando seu completo anonimato.

Os resultados da pesquisa serão divulgados em congressos e revistas científicas, ficando garantido a todos os participantes o sigilo quanto a sua identificação. 
A sua participação nesta pesquisa não acarretará gasto financeiro, e, portanto, não está previsto reembolso financeiro de qualquer natureza.

Abaixo, no rodapé constam as informações referentes ao Comitê de Ética em Pesquisa ao qual este estudo foi submetido. Para quaisquer esclarecimentos referentes aos aspectos éticos da pesquisa, entrar em contato com este comitê.

Este termo foi elaborado em duas vias, sendo que uma das cópias ficará com você enquanto a outra será arquivada pelo pesquisador.

Eu li a proposta acima e entendi os procedimentos. Eu me disponho a participar deste estudo.

Nome do Participante:

Assinatura:

Participam deste estudo:

Ricardo Marinho de Mello de Picoli, aluno de Mestrado em Psicobiologia.

Prof. Dr. José Lino Oliveira Bueno, orientador do projeto.

Faculdade de Filosofia, Ciências e Letras de Ribeirão Preto USP.

Av. dos Bandeirantes, 3900 - Ribeirão Preto - SP CEP: 14040-901.

Telefone para contato: (16) 3315-3697

E-mail: jldobuen@ffclrp.usp.br (José Lino) / rmmpicoli@gmail.com (Ricardo)

de de 2015.

Ricardo Marinho de Mello de Picoli

José Lino Oliveira Bueno

Comitê de Ética em Pesquisa

Faculdade de Filosofia, Ciências e Letras de Ribeirão Preto - USP

Avenida Bandeirantes, 3900 - bloco 3 - sala 16 - 14040-901 - Ribeirão Preto - SP - Brasil

Fone: (16) 3315-4811 / Fax: (16) 3633-2660

E-mail: coetp@ffclrp.usp.br 


\title{
APÊNDICE B - TERMO DE CONSENTIMENTO LIVRE E ESCLARECIDO
}

\author{
UNIVERSIDADE DE SÃO PAULO \\ Faculdade de Filosofia, Ciências e Letras de Ribeirão Preto \\ Departamento de Psicobiologia
}

TERMO DE CONSENTIMENTO LIVRE E ESCLARECIDO

Seu filho e/ou menor sob sua tutela legal está sendo convidado a participar de uma pesquisa pertencente ao projeto intitulado "Alterações dos estados de ânimo pré-evento em jovens atletas de futebol", cujo objetivo é avaliar as alterações dos estados emocionais presentes do jogador de futebol de campo durante o decorrer de um período competitivo.

Num evento de jogo, antes da preleção, no vestiário, ele receberá uma lista com quarenta frases escritas na primeira pessoa do singular, as quais nomeiam os estados emocionais. Num evento de treinamento, ele receberá a mesma lista antes de entrar no campo de treinamento em local reservado no mesmo espaço do treinamento. Este instrumento torna possível medir a presença de emoções do indivíduo no instante em ele que está respondendo a lista de frases.

Espera-se com esta pesquisa entender melhor e verificar como o estado emocional do atleta é alterado no decorrer de um período de competição em função da enormidade de variáveis que existem no contexto esportivo e, a partir disso, possibilitar à comissão técnica de clubes de futebol ter mais subsídios para trabalhar na melhoria do desempenho e bem-estar dos jogadores.

A participação na pesquisa não é obrigatória. Caso ele concorde em prosseguir como voluntário, ele também será livre para interromper a sua participação a qualquer momento e, se assim o fizer, não haverá prejuízos de qualquer ordem em função desta decisão.

O procedimento adotado neste estudo não apresenta riscos previsíveis à sua saúde física ou mental, não envolvendo qualquer droga ou medicamento, nem procedimentos invasivos.

Após a participação do atleta, será garantido a ele o recebimento de esclarecimentos atualizados sobre qualquer etapa deste trabalho. As informações obtidas serão utilizadas para trabalhos científicos, porém a identificação dos atletas será mantida em sigilo, isto é, não haverá chance de ser identificado o seu nome e imagem, assegurando seu completo anonimato.

Os resultados da pesquisa serão divulgados em congressos e revistas científicas, ficando garantido a todos os participantes o sigilo quanto a sua identificação.

A participação do seu filho nesta pesquisa não acarretará gasto financeiro, e, portanto, não está previsto reembolso financeiro de qualquer natureza. 
Abaixo, no rodapé constam as informações referentes ao Comitê de Ética em Pesquisa ao qual este estudo foi submetido. Para quaisquer esclarecimentos referentes aos aspectos éticos da pesquisa, entrar em contato com este comitê.

Este termo foi elaborado em duas vias, sendo que uma das cópias ficará com você enquanto a outra será arquivada pelo pesquisador.

Eu li a proposta acima e entendi os procedimentos. Eu autorizo a participação do meu filho neste estudo.

Nome do Participante:

Nome do Responsável:

RG:

Assinatura do Responsável:

Participam deste estudo:

Ricardo Marinho de Mello de Picoli, aluno de Mestrado em Psicobiologia.

Prof. Dr. José Lino Oliveira Bueno, orientador do projeto.

Faculdade de Filosofia, Ciências e Letras de Ribeirão Preto USP.

Av. dos Bandeirantes, 3900 - Ribeirão Preto - SP CEP: 14040-901.

Telefone para contato: (16) 3315-3697

E-mail: jldobuen@ffclrp.usp.br (José Lino)/rmmpicoli@gmail.com (Ricardo)

de de 2015

Ricardo Marinho de Mello de Picoli

José Lino Oliveira Bueno

Comitê de Ética em Pesquisa

Faculdade de Filosofia, Ciências e Letras de Ribeirão Preto - USP

Avenida Bandeirantes, 3900 - bloco 3 - sala 16 - 14040-901 - Ribeirão Preto - SP - Brasil

Fone: (16) 3315-4811 / Fax: (16) 3633-2660

E-mail: coetp@ffclrp.usp.br 
ANEXO A - LISTA DE ESTADOS DE ÂNIMO PRESENTES (ENGELMANN, 1986)

NOME:

IDADE:

DATA:

1

Assinale com um ' $X$ ' a posição em que você joga:

( ) Goleiro ( ) Defesa ( ) Meio-campo ( )Ataque

\section{INSTRUÇÕES DE PREENCHIMENTO}

No fim dessas instruções você encontrará uma lista de expressões capazes de identificar seus sentimentos. Use a lista com o objetivo de identificar seu sentimento ou estado no momento em que você lê as palavras.

Se as palavras descreverem intensidade 1 (um) o que você sente naquele instante, faça um ' $\mathrm{X}$ ' no primeiro espaço após a expressão. Assim, por exemplo, se na hora de você ler a expressão

"Estou aborrecido( $a$ )", você sentir muito fraco este estado, ponha o ' $\mathrm{X}$ ' do seguinte modo:

\begin{tabular}{|l|l|l|l|l|l|}
\hline Estou aborrecido(a) & $\mathrm{X}$ & & & & \\
\hline
\end{tabular}

Se as palavras descreverem intensidade 2 (dois) o que você sente naquele instante, faça um ' $\mathrm{X}$ ' no segundo espaço após a expressão. Assim, por exemplo, se na hora de você ler a expressão "Sinto-me calmo(a)", você sentir fraco este estado, ponha o ' $\mathrm{X}$ ' do seguinte modo:

\begin{tabular}{|l|l|l|l|l|l|} 
Sinto-me calmo(a) & & $\mathrm{X}$ & & & \\
\hline
\end{tabular}

Se as palavras descreverem intensidade 3 (três) o que você sente naquele instante, faça um ' $\mathrm{X}$ ' no terceiro espaço após a expressão. Assim, por exemplo, se na hora de você ler a expressão "Sinto-me despreocupado(a)", você sentir mais ou menos este estado, ponha o ' $\mathrm{X}$ ' do seguinte modo:

\begin{tabular}{|l|l|l|l|l|l|}
\hline Sinto-me despreocupado(a) & & & $\mathrm{X}$ & & \\
\hline
\end{tabular}

Se as palavras descreverem intensidade 4 (quatro) o que você sente naquele instante, faça um ' $\mathrm{X}$ ' no quarto espaço após a expressão. Assim, por exemplo, se na hora de você ler a expressão "Sintome enamorado( $a$ )', você sentir presente este estado, ponha o ' $\mathrm{X}$ ' do seguinte modo:

\begin{tabular}{|l|l|l|l|l|l|} 
Sinto-me enamorado(a) & & & & $\mathrm{X}$ & \\
\hline
\end{tabular}

Se as palavras estão fortemente presentes, descrevem intensidade 5 (cinco) o que você sente naquele instante, faça um ' $X$ ' no último espaço após a expressão. Assim, por exemplo, se na hora de você ler a expressão "Sinto-me surpreso(a)", você sentir fraco este estado, ponha o ' $\mathrm{X}$ ' do seguinte modo:

\begin{tabular}{|l|l|l|l|l|l|} 
Sinto-me supreso(a) & & & & & $\mathrm{X}$ \\
\hline
\end{tabular}

OBSERVAÇÃO:

1. Trabalhe rapidamente. SUA PRIMEIRA REAÇÃO É A MELHOR.

2. Por favor, não pule nenhuma linha. MARQUE CADA EXPRESSÃO. 


\begin{tabular}{|c|c|c|c|c|c|}
\hline & 1 & 2 & 3 & 4 & 5 \\
\hline \multicolumn{6}{|c|}{ 01-Estou aceitando alguma coisa } \\
\hline \multicolumn{6}{|c|}{ 02-Sinto uma admiração por alguém } \\
\hline \multicolumn{6}{|l|}{ 03-Estou alegre } \\
\hline \multicolumn{6}{|l|}{ 04-Sinto um alívio } \\
\hline \multicolumn{6}{|c|}{ 05-Sinto atração sexual por alguém } \\
\hline \multicolumn{6}{|l|}{ 06-Sinto-me calmo(a) } \\
\hline \multicolumn{6}{|l|}{ 07-Estou com calor } \\
\hline \multicolumn{6}{|l|}{ 08-Estou cansado(a) } \\
\hline \multicolumn{6}{|l|}{ 09-Estou cheio(a) } \\
\hline \multicolumn{6}{|l|}{ 10-Sinto ciúme de alguém } \\
\hline \multicolumn{6}{|l|}{ 11-Estou conformado(a) } \\
\hline \multicolumn{6}{|c|}{ 12-Estou tomando cuidado } \\
\hline \multicolumn{6}{|l|}{ 13-Sinto-me culpado(a) } \\
\hline \multicolumn{6}{|l|}{ 14-Sinto um desejo } \\
\hline \multicolumn{6}{|l|}{ 15-Estou com esperança } \\
\hline \multicolumn{6}{|l|}{ 16-Acho algo estranho } \\
\hline \multicolumn{6}{|l|}{ 17-Estou com fome } \\
\hline \multicolumn{6}{|l|}{ 18-Estou com frio } \\
\hline \multicolumn{6}{|c|}{ 19-Estou gostando de alguém } \\
\hline \multicolumn{6}{|c|}{ 20-Acho algo gozado } \\
\hline \multicolumn{6}{|l|}{ 21-Sinto-me humilhado(a) } \\
\hline \multicolumn{6}{|c|}{ 22-Sinto-me interessado(a) } \\
\hline \multicolumn{6}{|l|}{ 23-Sinto inveja de alguém } \\
\hline \multicolumn{6}{|l|}{ 24-Estou com medo } \\
\hline \multicolumn{6}{|l|}{ 25-Sinto uma necessidade } \\
\hline \multicolumn{6}{|l|}{ 26-Estou com nojo } \\
\hline 27-Sinto uma obrigação & & & & & \\
\hline 28-Sinto-me orgulhoso(a & & & & & \\
\hline 29-Tenho pena de algué & & & & & \\
\hline 30-Faço pouco caso de a & & & & & \\
\hline 31-Tenho raiva & & & & & \\
\hline 32-Estou refletindo & & & & & \\
\hline 33-Sinto saudade de alg & & & & & \\
\hline 34-Estou com sede & & & & & \\
\hline 35-Estou sem graça & & & & & \\
\hline 36-Estou com sono & & & & & \\
\hline 37-Sinto-me surpreso(a) & & & & & \\
\hline 38-Acabo de levar um st & & & & & \\
\hline 39-Sinto-me triste & & & & & \\
\hline 40-Estou com vergonha & & & & & \\
\hline
\end{tabular}

